\title{
LA TEMÁTICA PASTORIL EN LOS LIBROS DE CABALLERÍAS DE LA ÉPOCA DE FELIPE II $^{1}$
}

\section{Consideraciones PRELIMINARES}

El bucolismo impregnó no sólo gran parte de la literatura sino también de la vida cortesana del siglo Xvi. Es conocido el gusto de Isabel de Valois, la princesa Juana o María de Austria por los festejos en los que predominaba la temática pastoril. Un curioso detalle de la biografía de Felipe II nos ofrece un interesante testimonio de la influencia de lo bucólico en la vida social de su época: el monarca viajó de incógnito y disfrazado de pastor para poder contemplar a su futura esposa sin ser reconocido ${ }^{2}$. Por otra parte, el auge del bucolismo en el ámbito cortesano de este monarca se revela asimismo en las representaciones y fiestas cortesanas ${ }^{3}$.

La aparición de La Diana de Jorge de Montemayor supuso la creación de un modelo narrativo que adoptaba la temática pastoril como recurso de análisis sentimental. Su éxito fue rotundo; en la época de Felipe II se realizaron más de veinte ediciones; a los cinco años de su aparición vieron la luz dos continuaciones, la de Alonso Pérez y la de Gaspar de Gil Polo; poco después

${ }^{1}$ Este trabajo se ha hecho en el marco del proyecto Gran Enciclopedia Cervantina-Versión Digital, proyecto concedido por el Ministerio de Educación con referencia: HUM2006-06393, y dentro de las actividades del grupo de Investigación de la Universidad de Alcalá-Comunidad de Madrid, "Seminario de Filología Medieval y Renacentista”, con referencia: CCG06-UAH/ HUM-0680.

${ }^{2}$ Luis Fernández y Fernández de Retana, España en tiempo de Felipe II, t. 19 de la Historia de España que dirigió Ramón Menéndez Pidal, EspasaCalpe, Madrid, 1958, pp. 177-200.

${ }^{3}$ Teresa Ferrer Valls, "Bucolismo y teatralidad cortesana bajo el reinado de Felipe II”, Voz y Letra, 1999, núm. 10, 3-18, esp. p. 14. 
surgieron numerosas obras compuestas a imitación de La Dia$n a$, que conformaron el género de la novela pastoril. Entre sus seguidores se encuentran Cervantes -que inició su producción narrativa precisamente con un libro de pastores, La Galatea, de 1585-, así como Lope de Vega, que publicó en 1599 La Arcadia. Junto a esta eclosión de la novela pastoril, no hemos de olvidar la pervivencia de las églogas líricas que siguen la estela de Garcilaso, "príncipe de los poetas castellanos" ${ }^{4}$. Por último, también continuó la otra vertiente de la literatura pastoril, la derivada de las églogas de Juan del Encina, de forma que la figura del pastor rústico y jocoso puede encontrarse en la época en compañía de ese otro pastor idealizado de comportamiento cortesano ${ }^{5}$.

El éxito de los libros de pastores en la segunda mitad del siglo XVI parece que viene a coincidir con un período de declive de los libros de caballerías. Frente a una ingente producción caballeresca en las primeras décadas de este siglo, el número de títulos descendió a partir de la década de los años cincuenta. Todo parece indicar un relevo motivado por un cambio de gustos; existe la opinión de que en la época filipina se abandonaron los medievalizantes libros de caballerías para acoger la gran novedad que suponía el género creado por Jorge de Montemayor.

Sin embargo, un análisis más profundo lleva a conclusiones distintas. Por una parte, si bien es cierto que el número de libros de caballerías decayó en la segunda mitad del siglo XVI, aun así la producción no desapareció, sino que mantuvo un número considerable de obras. Por otra parte, el descenso de impresiones no implica necesariamente un cambio de gusto, pues es probable que se deba a las diversas crisis que la imprenta española sufrió en determinados momentos del siglo, tal como apuntaron con acierto Alvar y Lucía Megías ${ }^{6}$. También se ha de considerar la transmisión manuscrita del género, transmisión constatable que indica un interés todavía vigente incluso

\footnotetext{
${ }^{4}$ Sobre la poesía bucólica en el siglo xvi, véase Soledad Pérez-Abadín BARro, Resonare silvas. La tradición bucólica en la poesía del siglo XVI, Universidade, Santiago de Compostela, 2004.

${ }^{5}$ Algo lógico, si tenemos en cuenta que la figura del pastor enamorado también aparecía en la producción enciniana.

${ }^{6}$ Carlos Alvar y José Manuel Lucía Megías, "Los libros de caballerías en la época de Felipe II", en Silva. Studia philologica in honorem Isaías Lerner, eds. I. Lozano Rinieblas y J. C. Mercado, Castalia, Madrid, 2001, pp. 25-35.
} 
en el siglo XVII por los libros de caballerías ${ }^{7}$. Por tanto, no se puede pensar que las producciones caballerescas carecieran de atractivo para el público de la época de Felipe II; muy al contrario, el mismo público que se entusiasmaba con la obra de Montemayor no desdeñaba los textos que narraban las hazañas y los amores de los caballeros andantes.

No hemos de olvidar que la temática pastoril y la ficción caballeresca fueron de la mano en numerosas ocasiones. Así se constata en la recepción de la época; en los espectáculos cortesanos, por ejemplo, las representaciones caballerescas y pastoriles compartían en ocasiones un mismo espacio dramático; esto se observa también en las fiestas y justas poéticas, en cuyas relaciones se alude a veces a desfiles de personajes tanto caballerescos como bucólicos ${ }^{8}$; asimismo, las críticas de los moralistas a la literatura de ficción hablaban indistintamente de los libros del Amadís y los de La Diana ${ }^{9}$. Por otra parte, es sabido que Feliciano de Silva introdujo numerosos elementos pastoriles en varias de sus obras antes de la aparición de La Dia$n a$, tal como ha mostrado Cravens ${ }^{10}$. Es más, existió una estrecha relación entre Feliciano de Silva -el más reconocido de los continuadores de la saga amadisiana- y Jorge de Montemayor; el portugués recuerda diversos momentos de la producción caballeresca de Silva en su novela e incluso compuso una "Elegía a la muerte de Feliciano de Silva" ${ }^{11}$. Pero, si la influencia de

${ }^{7}$ J.M. Lucía Megías, "Libros de caballerías manuscritos", Voz y Letra, 1997, núm. 7, 61-125.

${ }^{8}$ Sobre justas poéticas, si bien centrado en el ámbito sevillano, resulta interesante L. Gómez Godoy, Las justas poéticas en la Sevilla del Siglo de Oro. (Estudio del código literario), Diputación, Sevilla, 2004.

${ }^{9}$ Elisabetta Sarmatti, Le critiche ai libri di cavalleria nel cinquecento spagnolo (con uno sguardo sul seicento). Un'analisi testuale, Giardini Editori e Stampatori, Pisa, 1996. En la selección de textos que la investigadora italiana ofrece se constata frecuentemente una crítica que englobaba tanto la ficción caballeresca como la pastoril.

${ }^{10}$ Sydney P. Cravens, Feliciano de Silva y los antecedentes de la novela pastoril en sus libros de caballerías, Estudios de Hispanófila-Albatros, ChapelHill-Valencia, 1976.

${ }^{11}$ En esta composición Jorge de Montemayor hace que la poesía lamente la pérdida de Silva: "Perdí mi bien, perdí mi Feliciano; / muerta es la gracia, el ser, la sotileza, / la audacia, ingenio, estilo sobrehumano"; por su parte, también Apolo llora la muerte de Feliciano: "¿Quién las hazañas cuenta belicosas?; / ¿quién los amores castos e aventuras?, / ¿quién las batallas fieras e dudosas?" (Poesía completa, ed. J.B. Avalle-Arce con la colab. de E. Blanco y J.A. de Castro, Madrid, 1996, pp. 576-580). El portugués, además 
Silva se dejó notar en el primer libro de pastores, éste también marcó en este sentido la producción caballeresca posterior. En nuestra opinión, la recurrencia de lo pastoril en los libros de la segunda mitad del siglo Xvi se debe a un proceso de acentuación de rasgos ya existentes en el género desde las aportaciones de Feliciano de Silva ${ }^{12}$. No se trata de fusión genérica, pues el nacimiento de los libros de pastores no fue absolutamente independiente, ni mucho menos, de la temática pastoril reflejada en los libros de caballerías de Silva. No obstante, lo que sí parece evidente es que tras la aparición de La Diana, la forma de tratar el bucolismo cambia debido a que la obra de Montemayor se convirtió también en modelo de imitación para aquellos autores de libros de caballerías que decidieron incorporar episodios pastoriles en sus obras. En definitiva, la influencia de Montemayor en el bucolismo de los libros de caballerías posteriores no hizo sino matizar una orientación ya existente en el género por lo menos desde 1530, fecha del Amadís de Grecia del autor de Ciudad Rodrigo.

El bucolismo y lo caballeresco estructuran los dos espacios imaginarios más recurrentes en el siglo xvi, y no resulta extraño que ambos conformen un único ámbito de ficción. De esta forma, cinco de los ocho libros de caballerías originales impresos durante el reinado de Felipe II acogieron en sus páginas elementos bucólicos: Olivante de Laura (1564) de Antonio de Torquemada, Febo el troyano (1576) de Esteban Corbera, la Segunda parte de Espejo de príncipes y caballeros (1580) de Pedro de la Sierra, Rosián de Castilla (1586) de Joaquín Romero de Cepeda y la Tercera parte de Espejo de príncipes y caballeros (1587) de Marcos Martínez. Tan sólo dos textos de este período carecen de este tipo de episodios, el Felixmarte de Hircania (1556) de Melchor Ortega y el Belianís de Grecia (partes III y IV) (1579) de Jerónimo Fernández.

Esto evidencia que en la segunda mitad del siglo XvI, el escenario arcádico se había incorporado plenamente al resto de los ámbitos en los que campeaba el héroe caballeresco. Ahora bien, el elemento bucólico no siempre fue tratado de la misma

de este poema, compuso un "epitaphio a la sepultura de Feliciano de Silva", ed. cit., p. 580. Todo esto lleva a la conclusión de que Silva y Montemayor se conocían y admiraban.

${ }^{12}$ Incluso se ha llegado a pensar que ya en el Amadís de Gaula se encontraban algunos elementos bucólicos, véase E.C. RiLEy, "A premonition of pastoral in Amadís de Gaula”, BHS, 59 (1982), pp. 226-229. 
forma en todos estos libros: su función narrativa dentro del texto, sus elementos constitutivos, la estructura de los episodios pastoriles, resultan diferentes en cada uno de ellos, aunque es cierto que tendieron a adoptar una serie de tópicos básicos que servían para remitir al lector al mundo pastoril conformado en la mente de éste a partir no sólo de los rasgos ofrecidos por el texto en cuestión, sino también por la relación que estos rasgos establecían con otros textos -narrativos, líricos y dramáticosanteriores.

\section{Olivante de LaURa (1564), De Antonio de Torquemada}

La impronta pastoril de Silva y Montemayor de forma conjunta se puede observar en el Olivante de Laura, de Antonio de Torquemada; en esta obra el elemento pastoril determina un episodio sentimental del héroe -Olivante se disfraza de pastor para estar cerca de su amada Lucenda- y marca toda la vida erótica de otro de los personajes: Silvano, enamorado de Galarcia (hermana de Olivante).

Los elementos bucólicos presentes en el Olivante de Laura fueron analizados por Muguruza Roca ${ }^{13}$, quien estudió la onomástica, la inserción de fragmentos poéticos, el sentimiento de la naturaleza y la espiritualización del amor de los episodios pastoriles del Olivante; la estudiosa destacó el carácter eminentemente pastoril de estos elementos, al tiempo que analizó cómo esos elementos se reestructuraron para formar parte de un libro de caballerías. La investigadora llegó a la conclusión de que Torquemada posiblemente conocía la obra de Montemayor, de la que tomó, entre otros elementos, el nombre de Silvano para uno de sus personajes pastoriles. Asimismo, destacó la influencia que la obra de Feliciano de Silva ejerció sobre el Olivante de Lau$r a$, y mencionó expresamente la historia sentimental de Florisel por Silvia en el Amadís de Grecia $(1530)^{14}$. Silva había introducido en esta obra una historia pastoril estructurada precisamente alrededor de la transformación del héroe en pastor por amor a una dama. Feliciano narra que Silvia es una hermosa pastora

${ }^{13}$ I. Muguruza, "El pastor en los libros de caballerías: el caso del Olivante de Laura, de Antonio de Torquemada”, CuLH, 1995, núm. 20, 197-215.

${ }^{14}$ Hay ed. moderna de esta obra: Feliciano de Silva, Amadís de Grecia, eds. A.C. Bueno Serrano y C. Laspuertas Sarvisé, Centro de Estudios Cervantinos, Alcalá de Henares, 2004. 
por cuya belleza numerosos pastores se dedican a servirla enamorados, sin que ninguno haya sido aceptado por la honesta doncella. Incluso personajes de alta alcurnia han abandonado todo por amor a la dama y, para estar cerca de ella, viven como pastores. Entre ellos se encuentra Florisel, que tampoco será aceptado por la pastora. Finalmente, se descubre que Silvia no es en realidad una pastora, sino una alta dama, tía de Florisel, lo que explica su honesto comportamiento y su extremada hermosura. Este motivo es el que, según Muguruza, influyó en el autor del Olivante: el héroe, al igual que Florisel, adopta la personalidad pastoril para poder estar cerca de su amada. La estudiosa recordó también que en el Primaleón, don Duardos se disfrazaba de hortelano para estar cerca de su dama (se trata del célebre momento que Gil Vicente dramatizó en su obra Don Duardos $)^{15}$. De esta manera, la transformación del caballero en pastor (hortelano) es una de las posibilidades que, desde el Primaleón (1512) y el Amadís de Grecia (1530) formaron parte de los libros de caballerías, incluso antes de la aparición de La Diana de Montemayor.

Ahora bien, aunque todo ello es cierto, me parece probable que la transformación de Olivante estuviera más influida por otra obra de Silva, la Cuarta parte de Florisel de Niquea (1551), en la que se produce una situación más cercana a la que narra Torquemada. En la Cuarta parte de Florisel de Niquea, el héroe (Rogel de Grecia) se disfraza de pastor para estar cerca de su amada (la emperatriz Arquisidea de los Imperios Orientales). La comparación entre este texto de Feliciano y el de Torquemada ofrece un mayor número de paralelismos frente a la comparación del Olivante y el Amadís de Grecia: 1) Lucenda, al igual que Arquisidea, es una dama noble y no una pastora; 2) Olivante, como Rogel, se ve forzado a disfrazarse de pastor para poder acercarse a su amada sin levantar sospechas sobre su honra, ya que 3) la diferencia de estados, que imposibilita cualquier relación entre ellos, es la mejor garantía para la joven.

En la ficción quinientista las damas podían conversar y tratar con personajes de clase inferior, incluso a solas, algo impensable si el hombre era de su mismo estado. Con el disfraz pastoril, Olivante puede descubrir su amor por Lucenda sin amenazar su honra. Se trata de la misma estratagema de don Duardos en el

${ }^{15}$ Art. cit., p. 211. Véase la ed. moderna: Primaleón, ed. M.C. Marín Pina, Centro de Estudios Cervantinos, Alcalá de Henares, 1998. 
Primaleón, pero en el Olivantey en el Florisel de Niquea los héroes no se transforman en hortelanos (trabajadores de la corte) sino en pastores, pues en las fechas en que aparecen estas obras el mundo pastoril, por su representación literaria idealizada, había entrado a formar parte -como adorno musical y colorido- de las ilustres cortes caballerescas. De ahí que se contemplara la posibilidad de que un pastor viviera en una corte al servicio de alguna dama.

Así, Olivante no se convierte en pastor porque su amada sea una pastora (como sucede en la historia de Florisel y Silvia), sino que adopta la personalidad pastoril para poder estar cerca de una alta dama sin levantar sospechas (como Rogel y don Duardos). Olivante no se despoja de su personalidad caballeresca, sino que se disfraza. En el Amadís de Grecia, Florisel sí la abandona, como recuerda a Silvia en alguna ocasión; de esta forma, ella conoce la verdadera identidad de su amante, lo que no sucede en el caso de Lucenda en el Olivante; Lucenda, profundamente enamorada de quien cree pastor, se atormenta al pensar que se degrada por amar a un ser de clase inferior. Por su parte, Arquisidea no siente nunca el más mínimo amor por el pastor Arquileo (esto es, Rogel disfrazado), sino por su verdadera identidad caballeresca, Rogel (ignorando en todo momento que se trata de la misma persona); esta confusión de identidades en la obra de Silva no se produce en el Olivante de Laura.

Pero, a pesar de estas variantes, parece claro que Torquemada tomó de la tradición caballeresca (Silva, Primaleón), la estrategia para incorporar el mundo pastoril a la narrativa de caballerías: la transformación del caballero en pastor por amor a una dama.

No obstante, la historia sentimental de Olivante no es el único momento en que aparece lo pastoril en esta obra. De hecho, la primera aparición de elementos bucólicos en el texto corresponde a la aparición de un pastor, Silvano, que sufre por su amor imposible por Galarcia, hermana de Olivante de Laura. Galarcia es una alta dama y, por tanto, se encuentra fuera del alcance del pobre pastor. Torquemada presenta a Silvano a través del tópico de la falsa soledad:

al qual tiempo oyendo tañer junto a la fuente, una churumbela de pastor muy dulce y sabrosamente, la estuvo escuchando, pareciéndole recebir con el suave son della algún alivio de su tormento, 
como para quien era tan necessario. Y despertando a Peliscán, que sin ningún cuydado estava durmiendo, los dos estuvieron atentos, pareciéndoles que jamás la uviessen visto tan graciosamente tocar. Y yendo muy passo por entre los árboles, sin que del que la tañía pudiessen ser sentidos, vieron que era un pastor... ${ }^{16}$

El bucolismo de esta aparición no puede resultar más evidente. Si bien la falsa soledad no es exclusiva, sí resulta muy propia de lo pastoril. Y lo mismo podría decirse de la invocación a la naturaleza, un lugar común en la literatura bucólica ${ }^{17}$. Resultan inevitables los recuerdos de Boscán y Garcilaso, éste último modelo constante en la lírica (y en la narrativa) posterior $^{18}$. Montemayor también hizo que sus personajes acudieran a la naturaleza para pedir ayuda, alivio o atención a sus males de amor. En el Olivante de Laura, Silvano no se limita a apostrofar a la naturaleza en sus lamentos, sino también en sus canciones. En concreto en el poema -en arte mayor castellano- "¡O montes, o valles, o sierras, collados!”, poema que Muguruza vinculó

${ }^{16}$ Antonio de Torouemada, Don Olivante de Laura, ed. I. Muguruza, Fundación José Antonio de Castro, Madrid, 1997, p. 216.

17 "O montes, valles deleytosos, florestas dulces y sabrosas, fuentes, arroyos y corrientes ríos, suaves flores y rosas que en esta dulce floresta se produzen... resonad con el desdichado Silvano las dolorosas quexas, las tristes desventuras de la mayor y más dichosa ventura suya. Parleras aves que aposentadas en los floridos árboles escucháis las lamentaciones..., publicad juntamente comigo con vuestras harpadas lenguas la causa de mi dolor..." (Olivante de Laura, p. 216).

${ }^{18}$ En GARCilaso encontramos las invocaciones a la naturaleza más conocidas ("Con mi llorar las piedras enternecen / su natural dureza y la quebrantan / los árboles parece que s'inclinan / las aves que m'escuchan, cuando cantan, / con diferente voz se condolecen / y mi morir cantando m’adevinan" o "Corrientes aguas puras, cristalinas, / árboles que os estáis mirando en ellas, / verde prado de fresca sombra lleno, / aves que aquí sembráis vuestras querellas, / hiedra que por los árboles caminas...", Égloga primera, en sus Poesías castellanas completas, ed. E.L. Rivers, Castalia, Madrid, 1992, pp. 126 y 128 resp.); pero también en JuAn Boscán: "Claros y frescos ríos / que mansamente vais / siguiendo vuestro natural camino; / desiertos montes míos, / que'n un estado estáis / de soledad muy triste, de contino; / aves en quien ay tino / de descansar cantando; / árboles que bivís, / y en fin también morís, / y estáis perdiendo a tiempos y ganando, / oídme juntamente / mi voz amarga, ronca y tan doliente" (Obra completa, ed. C. Clavería, Cátedra, Madrid, 1999, pp. 148-149). Sobre la imitatio de Garcilaso, véase J.J. Martín Romero, "Garcilaso como objeto de imitación poética y de reescritura narrativa", en Memoria de la palabra. Actas del VI Congreso de la Asociación Internacional Siglo de Oro, eds. M.L. Lobato y F. Domínguez Matito, Iberoamericana-Vervuert, Madrid-Frankfurt/M., 2004, t. 2, pp. 1267-1275. 
no con los poetas mencionados sino con un momento de la Égloga de Fileno, Zambardo y Cardonio ${ }^{19}$.

La primera aparición de Silvano, por tanto, no puede resultar más adecuada a la imagen del pastor enamorado en la literatura bucólica: este personaje se presenta como pastor enamorado ("Ay amor poderoso, cuyas leyes van fuera de toda razón, pues en tan pequeño cimiento fundaste obra de tanta presunción y sobervia como en los pensamientos de un pobrezillo pastor" ${ }^{20}$ ), como pastor músico ("tornando al sabroso son de la churumbela, tañendo un poco y cantando otro poco, con una muy dulce y suave boz", $i d$.) y como pastor de expresión refinada, tal como reconocen los caballeros con los que se encuentra. Así, cuando en una ocasión Silvano se denomina "un desdeñado pastor", Olivante le responde: "No son palabras esas de quien voz dezís..., mas de muy alto sentimiento y subido juizio. No sé yo quién tras las ovejas os enseñó a hablar con tan prudentes razones llenas de tanta excelencia" (Olivante de Laura, p. 219). Silvano se presenta, por tanto, como uno más de los pastores idealizados de la bucólica, desde Garcilaso a Montemayor. Sin embargo, hemos de notar cómo Olivante se extraña de su comportamiento. En otras palabras, si en la literatura pastoril se presenta al pastor de forma idealizada comportándose como un cortesano, en el Olivante de Laura no se idealiza la figura del pastor. En la obra de Torquemada, los personajes esperan que los pastores se comporten como tales y que, por tanto, carezcan de la exquisitez de comportamiento de Silvano, que no duda en alegar su condición de enamorado para justificarse ("El amor - respondió el pastor-, que a los rudos haze sabios y a los que poco saben discretos, y a los mudos haze hablar, como a mí", $i d$.). Se trata de la conocida idea de que el amor mejora al amante. Pero parece ser que esta explicación no basta, pues finalmente se descubrirá que Silvano no es en realidad un pastor, sino que desciende del emperador Constantino y de una hermosa pastora. Efectivamente, este personaje es noble por línea paterna; más aún, se trata del hermano (de padre) de Lucenda, la amada de Olivante. En definitiva, su comportamiento se explica no por su enamoramiento, sino que su enamoramiento (y conducta en general) se explica por su linaje noble. Silvano no es un pastor idealizado, es un héroe

${ }^{19}$ I. MuguruzA, art. cit., p. 207.

${ }^{20}$ Olivante de Laura, p. 217. 
idealizado que vive como pastor al desconocer su origen noble. Pues bien, esa situación - personaje de origen noble que se cría como pastor al desconocer su ascendencia- es la misma por la que pasa Silvia en el Amadís de Grecia de Feliciano.

En conclusión, Torquemada construye un episodio pastoril con dos protagonistas: por un lado, Silvano y, por otro, el propio héroe $^{21}$. El elemento bucólico en cada uno de ellos responde a dos tópicos que ya aparecían en la obra de Feliciano de Silva: en el caso de Silvano, se trata de la historia del personaje que, habiendo sido criado como pastor, descubre finalmente su ascendencia noble, lo que explica su comportamiento extrañamente refinado y honesto; en el caso de Olivante, se trata del tópico de la transformación del caballero en pastor por amor a una alta dama, transformación que le permite una cercanía que, como caballero, le estaría vedada para evitar levantar sospechas. En definitiva, Torquemada reutiliza la historia de Silvia en el Amadís de Grecia para la biografía de Silvano, mientras que para la historia pastoril de Olivante acude al modelo que le ofrecía, en la Cuarta parte de Florisel de Niquea, el personaje de Rogel de Grecia, disfrazado de pastor bajo el nombre de Arquileo a causa del amor que siente por la emperatriz Arquisidea. Esos tópicos argumentales aparecen construidos con otros tópicos claramente (aunque no exclusivamente) pastoriles: la falsa soledad, el lamento de amor y la invocación a la naturaleza, pero no presentando un ambiente puramente pastoril, ya que no aparece la figura del pastor idealizado.

\section{Febo el Troyano (1576), de Esteban Corbera}

Febo el Troyano de Esteban Corbera es uno de los textos más peculiares de toda la producción narrativa de los Siglos de Oro. Corbera compuso su obra a modo de centón en el que fue incluyendo frases, párrafos, capítulos e incluso grupos de capítulos pertenecientes a otras obras ${ }^{22}$. El grado de transformación de esos elementos ajenos varía desde la copia casi literal (limitándose a transformar los nombres de los protagonistas) hasta la

\footnotetext{
${ }^{21}$ Aunque las dos historias sentimentales pastoriles terminan uniéndose.

${ }^{22}$ Cf. J.J. Martín Romero, "Febo el Troyano [1576] de Esteban Corbera: la reescritura caballeresca de la materia troyana”, Edad de Oro, 21 (2002), pp. 443-449.
} 
reelaboración propia de la práctica imitativa del Renacimiento $^{23}$. Los materiales que conforman este texto son de lo más heterogéneo y, entre ellos, se incluye un episodio de tono pastoril. Se trata de la contienda entre dos pastores que defienden opiniones contrarias sobre el amor y la mujer. Uno de ellos, Silvaneo, defiende con pasión la bondad del sentimiento amoroso y la valía del género femenino, mientras que el otro, llamado Lusitano, no comprende cómo puede alabarse una pasión que causa tantos males ni cómo puede elogiarse a la mujer, origen de este sentimiento. Estos pastores son secretamente observados por dos de los héroes del libro -Playartes y Aurealino-, que en un momento determinado intervienen para evitar que los dialogantes peleen. Tras haber detenido el enfrentamiento entre los pastores, los dos caballeros interrogan hábilmente a Lusitano sobre sus opiniones, hasta que finalmente consiguen convencerlo de su error. Con ello, se recoge, por tanto, la polémica entre misoginia y profeminismo tan frecuente desde el siglo XV y que, ya en el siglo xvi, el erasmismo adopta para centrarse en el proceso educativo de la mujer ${ }^{24}$.

Ahora bien, este episodio pastoril no deriva, frente a lo que pudiera pensarse, de ningún libro de pastores. Tampoco procede de ningún episodio bucólico de libros de caballerías, sino de una obra bien distinta: la Selva de aventuras de Jerónimo de Contreras.

${ }^{23}$ Sobre la imitación en los libros de caballerías estoy ultimando una monografía, parte de cuyas conclusiones ya presenté en el congreso Recovecos de Literatura Áurea, I Jornadas Internacionales de Jóvenes Filólogos (Oviedo 13-15 de octubre de 2004) con el título "La práctica de la imitatio poética en la narrativa renacentista. Los libros de caballerías" [en prensa]. Véanse, también, M.L. Cuesta Torre, "Adaptación, refundición e imitación: de la materia artúrica a los libros de caballerías”, Revista de Poética Medieval, 1997, núm. 1, 35-70; y "La teoría renacentista de la imitación y los libros de caballerías”, en Actas del Congreso Internacional sobre Humanismo y Renacimiento, coord. M. Pérez González, Universidad, León, 1998, pp. 297-304; E. SaleS DAsí, "La imitación en las continuaciones ortodoxas del Amadís de Gaula. I. Los episodios amorosos", en De la literatura caballeresca al Quijote, coord. J.M. Cacho Blecua, Prensas Universitarias, Zaragoza, 2007, pp. 395-417, y "La imitación en las continuaciones ortodoxas del Amadís. II. Las aventuras bélicas y maravillosas", Tirant, 2007, núm. 9; http://parnaseo.uv.es/Tirant/ Butlleti.9/ Sales_Imitaciones(2).htm.

${ }^{24}$ Cf. M. Pilar OÑate, El feminismo en la literatura española, Espasa-Calpe, Madrid, 1938. Rogelio Reyes Cano ofrece un panorama histórico del debate sobre la mujer en su Introducción a CAstillejo, Diálogo de mujeres, Castalia, Madrid, 1986, pp. 27-32. 
La Selva de aventuras apareció en 1565, y en 1583 vio la luz otra edición con un desenlace distinto. Teniendo en cuenta que Febo el Troyano data de 1576, es evidente que Corbera no pudo utilizar la edición de 1583, sino la versión anterior ${ }^{25}$.

En la obra de Jerónimo de Contreras, el protagonista, llamado Luzmán, llega a Venecia, "un día que en la plaza de San Marcos se representaba aquella tarde la memoria de la edificación y fundamento de aquella ciudad" 26 . Entre otras representaciones, contempla a dos actores vestidos con pellicos pastoriles que debaten, en verso tradicional castellano, sobre el amor y la mujer: uno de ellos, Ardonio, se presenta como ardiente defensor del amor, mientras que el otro, Floreo, alaba la vida libre de amores.

Pues bien, Corbera se limita a seguir muy de cerca este episodio de la obra de Contreras, prosificando los versos, amputando algunas partes y transformando la situación. De esta manera, el enamorado Silvaneo de Febo el Troyano toma las palabras de Ardonio, mientras que el desamorado Lusitano toma las de Floreo.

Sin embargo, se ha de tener en cuenta, en primer lugar, que la representación teatral dentro de la novela -el juego de metaficción- de la Selva de aventuras desaparece en Febo el Troyano, donde los dialogantes no son actores, sino pastores reales. Se trata, por tanto, de una polémica real dentro de la ficción. Esto fuerza a Corbera a prosificar los versos de Contreras, versos propios para el teatro, pero no adecuados para el reflejo de una conversación entre pastores en una narración en prosa. Pero, aún así, la elaboración literaria de Contreras se percibe en boca de los personajes de Corbera, personajes cuya expresión resulta demasiado teatral y tampoco se acerca mucho al lenguaje delicado de los pastores idealizados de Montemayor. Por otra parte, su actitud combativa, comprensible dentro de la representación en la obra de Contreras, resulta forzada en Febo el Troyano, si bien ese momento de violencia es aprovechado por Corbera para introducir en escena a los dos caballeros que espiaban escondidos la polémica. A partir de entonces, el desamorado Lusitano dialoga con los caballeros y demuestra sus opiniones misóginas.

${ }^{25}$ Véanse los comentarios sobre las dos versiones de la obra en la Introducción de M.A. Teijeiro Fuentes a su ed. de Jerónimo de Contreras, Selva de aventuras (1565-1583), Institución "Fernando el Católico"-Universidad de Extremadura, Cáceres, 1991, esp. pp. xiv-xxiv.

${ }^{26}$ Ed. cit., p. 16. 
Esta segunda parte de la polémica deriva directamente de otro pasaje distinto de la Selva de aventuras de Contreras. En concreto procede del momento en que Luzmán llega a Florencia en compañía del marqués Octavio, quien le propone que conozca al "hombre más enemigo de mujeres", que no es otro que el músico Soticles, que se dedica a exponer sus razonamientos contrarios al género femenino ante diversas doncellas que pretenden convencerlo de que está en un error. Las palabras del misógino Soticles son las que aparecen en boca del desamorado Lusitano de la obra de Corbera. Esta vez, puesto que imita un episodio en prosa, no ha de realizar casi ningún cambio, tan sólo aquéllos necesarios para adecuarlos a los nuevos interlocutores. De esta forma, cambian los nombres, las referencias pronominales y las personas verbales. Todo lo demás aparece prácticamente copiado, como puede comprobarse en el siguiente ejemplo:

Febo el Troyano

-Yo os digo -dixo Lusitanoque tenía por menos muerte la de las mugeres recebida por sus manos, aunque me la diessen muy cruel, antes que ser amado, ni amar a ninguna muger ${ }^{27}$.

\section{Selva de aventuras}

-Yo os digo, dijo Soticles, que tendría por menos muerte la vuestra, quiero decir, por vuestras manos recibida, aunque me la diésedes muy cruel, antes que ser amado ni amar a ninguna mujer ${ }^{28}$.

En este ejemplo se observa la sustitución del nombre (Lusitano por Soticles) y la transformación de referencia pronominal, pues el personaje no se dirige a mujeres, por lo que no puede hablar de ellas en segunda persona, sino en tercera (diésedes $\rightarrow$ diessen). Pero la copia es prácticamente literal y no deja lugar a dudas de que Corbera tenía ante los ojos la Selva de aventuras mientras (re) componía su Febo el Troyano.

En definitiva, Corbera no duda en incorporar un episodio pastoril a su heterogéneo libro de caballerías. Pero ese episodio pastoril se presenta como una unidad ajena al desarrollo de la trama general del libro. No se produce la transformación del caballero en pastor, como era frecuente en otros libros de caballerías, sino que se limita a la aparición de ese mundo bucólico,

${ }^{27}$ Esteban Corbera, Febo el Troyano, ed. J.J. Martín Romero, Centro de Estudios Cervantinos, Alcalá de Henares, 2005, pp. 189-190.

${ }^{28}$ Ed. cit., p. 73. 
con sus personajes propios -los pastores-y sus preocupaciones propias -mal de amores, disputa sobre la mujer, controversia sobre el amor-, ante los caballeros andantes, que no abandonan nunca su personalidad heroica, sino que imponen su superioridad jerárquica en dicho mundo para forzar a uno de estos pastores a admitir un punto de vista determinado sobre el amor.

El episodio pastoril, por tanto, se presenta como una unidad aislable e independiente del resto de la trama del libro. Esto no ha de sorprender, pues esta obra se compone mediante la incorporación de unidades más o menos independientes en una trama cuya unidad no se puede concebir únicamente desde la estructura hipotáctica.

Los pastores no volverán a aparecer y su encuentro con los dos caballeros no parece influir en la evolución heroica de éstos. Sin embargo, podemos considerar que este episodio se presenta como un contrapunto a la visión amorosa de uno de estos caballeros. Efectivamente, uno de los héroes que espían a los pastores es don Playartes de Dacia, caballero mancebo que dedica tanto ardor a sus aventuras bélicas como a las amorosas, dando muestras de un carácter inconstante e impulsivo en el amor. Recoge la tradición del caballero rijoso que tiene uno de sus máximos exponentes en Galaor, el hermano de Amadís de Gaula. Es bien sabido que Galaor no dudaba en complacer a las doncellas y dueñas, fueran solteras o casadas, que se encontraba en su deambular caballeresco. Recuérdese que en el Quijotese menciona que de "don Galaor, hermano de Amadís de Gaula, se murmura que fue más que demasiadamente rijoso" 29 .

Dentro de los descendientes amadisianos, Rogel de Grecia es sin duda el que expone mejor la filosofía amorosa heredada de Galaor. Rogel no duda en considerar "sandeces" las que impiden que satisfaga sus ansias amorosas con toda doncella que así lo quiera. Pues bien, las palabras de Rogel de Grecia, aparecidas en la Tercera parte de Florisel de Niquea, son recogidas de forma prácticamente literal en Febo el Troyano, y aparecen puestas en boca, claro está, de don Playartes de Dacia, el más ardoroso de los caballeros de esta obra ${ }^{30}$. Don Playartes defien-

${ }^{29}$ Miguel de Cervantes, El ingenioso hidalgo don Quijote de la Mancha, eds. F. Sevilla Arroyo y A. Rey Hazas, Centro de Estudios Cervantinos, Alcalá de Henares, 1994, p. 553.

${ }^{30}$ Don Playartes de Dacia deriva de Rogel de Grecia en la Tercera parte de Florisel de Niquea, pero también de don Filisel de Monte Espín en esa misma 
de, por tanto, ante el pastor Lusitano, el gozo y el valor del sentimiento amoroso; pero, si tenemos en cuenta su particular visión de dicho sentimiento, su defensa ha de interpretarse de manera distinta a la defensa ortodoxa del amor, esto es, aquella que propone que el amor es un sentimiento idealizado ajeno a lo carnal. Aunque don Playartes afirma todo esto, su comportamiento anterior (y posterior) deja entrever que la defensa del amor es también una defensa del goce de amar físicamente.

El episodio, a pesar de derivar de trozos literales de la Selva de aventuras, se estructura perfectamente, de forma que su fuente ha pasado hasta ahora inadvertida por los críticos. En este episodio se cuenta cómo los caballeros, en un momento de reposo, se dedican a buscar un lugar lo suficientemente agradable para pasar la hora de la siesta. La amenidad del lugar les anima a seguir buscando, ya que a cada paso encuentran un entorno cada vez más agradable. Ese proceso de búsqueda nos transmite una sensación de internamiento en un mundo natural, casi secreto, poco transitado y, en definitiva, apenas maculado por el ser humano ${ }^{31}$. Se recuerda el carácter natural del lugar, cuya belleza no se debe al artificio humano. Así, una fuente que refresca el paraje se presenta como resultado de la acción de la naturaleza:

obra, por lo que su comportamiento resulta extrañamente ambivalente. Por una parte, es el ejemplo del caballero que defiende el gozo sensual por encima de todo, y, por otra, se convierte en exponente del amor más apasionado y carnal (J.J. Martín Romero, Introducción a Febo el Troyano. Guía de lectura caballeresca, Centro de Estudios Cervantinos, Alcalá de Henares, 2003, p. 8).

31 "A la cual llegando, vieron una estrecha entrada y algo larga, cuyos lados no de paredes de artífice mano fabricados, mas de árboles de la maestra naturaleza compuestos estavan, que no menos el lugar silvestre era ennoblecido con la verdura natural que las pomposas cámaras con el oro assentado. Allí se vía el funesto ciprés, el triumfante laurel, la dura enzina, el frondoso sauce, la invencible palma, el resinoso pino, el blando y liso álamo, el negro y áspero olmo, unos con otros mezclados, cuyos troncos eran enlazados de la vivace yedra, de la fructífera parra, del oloroso yazmín y de otras yervas que en compañía más abundantemente crescen, entre los cuales como por fastidiossas jaulas saltando andavan haziendo el lugar más agradable con su dulce canto diversidad de silvestres paxaricos; de tal manera los árboles estavan puestos, que no se descomedían a que el claro sol entre ramas y hojas no entrasse variando el verde suelo de diversas colores que de las flores tomados reberverar hazían, los cuales jamás en un lugar assentados se vían, a causa de que las movibles hojas los inquietavan” (ed. cit., p. 184). 
Mirava esta fuente hazia a do el sol sale, algo declinada a la parte septentrional. El mismo pedernal por do salía el agua servía de boca y de canal, labrado no con el golpe del duro escoplo, mas con el continuo curso de la blanda agua, y assí estava en algunas partes d'él algo más gastado que en otras, porque creo devía estar más blando o, por mejor dezir, menos duro en un lugar que en otro, y esta desigualdad causava más graciosa corrida, porque hazía venir el agua muy alegre con los altos y baxos, que representavan unos claros y oscuros, graciosa cosa a la vista (ed. cit., p. 184).

En ese momento, contemplan la llegada de un pastor vestido de un pellico blanco (también es blanco el pellico de Ardonio en la Selva de aventuras), que canta, al son de su rabel, a su amada Marfida; en su canto acepta gustoso sus terribles tormentos, a cambio de la gloria de conocer a su amada; se muestra incluso dispuesto a perder "mil vidas":

Si nunca te mirara, ¡ó, mi Marfida!, jamás por ti penara, pues no viera un rostro que da junto muerte y vida.

Pero tampoco te no conociera, $y$, en no te conocer, por conocerte mil vidas de una muerte suspendiera (ed. cit., p. 185).

La situación no puede ser más propia de la literatura pastoril: "amor desdeñado, goce de la naturaleza, desesperación, soledad y música” son elementos que Avalle-Arce reconoce como pastoriles en los episodios bucólicos de Feliciano de Sil$v^{32}$ y que también vemos en este pasaje. A eso hemos de añadir que también se encuentra aquí el tópico de la falsa soledad, esto es, un personaje que se lamenta piensa estar a solas, pero es secretamente contemplado o escuchado por otro personaje. El pastor del Febo el Troyano, llamado Silvaneo, cree estar solo al cantar su canción, pero en realidad lo espían los dos caballeros $^{33}$. Esta falsa soledad en el mundo pastoril implica el encuentro de dos o más personajes. Es frecuente, cuando se va a insertar un relato en la historia principal, que aparezca un personaje en circunstancias que despiertan el interés de otros personajes y del lector, como indica González

${ }^{32}$ J. B. Avalle-Arce, La novela pastoril española, Istmo, Madrid, 1974, p. 38.

${ }^{33}$ Ibid., p. 39. 
Rovira $^{34}$. Son múltiples las variantes de "tópica del encuentro", pero entre ellas se destacan "el lamento pastoril, la persecución rural, el retiro ermitaño, el lance de espadas, la prisión, el navío o, como cualquier lector del Quijote recordará, la mera coincidencia en el camino o la posada" $(i d$.).

Estas consideraciones sobre el inicio del relato interpolado también son ciertas en el caso de la narrativa pastoril, en la que ese encuentro se formula en muchas ocasiones, tal como indica González Rovira, a través del lamento pastoril. Y habría que añadir que ese lamento pastoril funciona como elemento de encuentro precisamente gracias al tópico de la falsa soledad ${ }^{35}$.

Sin embargo, en Febo el Troyano notamos que no todo está en su sitio, que, aunque Corbera pretende introducirnos en el mundo arcádico de pastores idealizados, no todo cuadra. En primer lugar, la forma más frecuente de falsa soledad es descubrir por el oído la presencia de alguien que se cree solo, no, como sucede en esta obra, a través de la vista. Aquí, frente a lo esperable, no es el lamento o la canción la que revela la presencia de una persona, sino que directamente los testigos la ven llegar y comenzar a cantar.

Por otra parte, Corbera hace hablar solo a este pastor, con la intención de informar al lector de algunos detalles. Todo esto revela el origen "teatral" del fragmento, si bien ese soliloquio del pastor no deriva de la Selva de aventuras. Ese tono teatral se percibe a lo largo de la polémica discusión entre los dos pastores, que se inicia cuando, tras haber cantado sus penas de amor por Marfida, este pastor, llamado Silvaneo, comenta en voz alta que ve a otro, al que llama Lusitano. Silvaneo increpa directamente a su compañero sin dedicarle saludo alguno. Los insultos, formulados literariamente (recordemos que derivan del lenguaje poético de la Selva de aventuras), dan paso a las manos, momento en que, como ya se ha indicado, los caballeros salen de su escondite y detienen la pendencia.

Por último, el episodio no se centra en una determinada historia de amor. El relato amoroso deja paso a la discusión teórica

${ }^{34}$ Javier González Rovira, "Poética y retórica del relato interpolado", en Actas del IV Congreso Internacional de la Asociación Internacional Siglo de Oro (AISO), Universidad, Alcalá de Henares, 1998, t. 1, pp. 741-750 (la cita, en p. 742).

${ }_{35}$ No obstante, aquí no se introduce ningún relato interpolado, sino un debate sobre el amor. Pero lo relevante es que funciona como tópico narrativo. 
sobre el amor entre dos pastores. Nada sabemos del desenlace de los tristes amores de Silvaneo por Marfisa, amores que, por otra parte, sólo se mencionan en su canto. Tampoco sabremos si Lusitano caerá en las redes de Amor o se mantendrá ajeno a estas preocupaciones. Estos pastores, que no vuelven a aparecer en el libro, sirven tan sólo para incluir el elemento pastoril en el texto. El episodio carece de desarrollo posterior en la trama de la obra, de igual manera que la representación veneciana o el músico Soticles en la Selva de aventuras.

SEGUNDA PARTE DE ESPEJO DE PRÍNCIPES Y CABALLEROS (1580), de Pedro de la Sierra

La Segunda parte de Espejo de príncipes y caballeros de Pedro de la Sierra salió de las prensas complutenses de Juan Íñiguez de Lequerica en 1580. Se trata de la continuación de uno de los libros de caballerías de mayor éxito, el Espejo de príncipes y caballeros de Diego Ortúñez de Calahorra, de 1555. Su protagonista, el Caballero del Febo, fue tan conocido que su nombre figura al lado de Amadís en la definición de libros de caballerías que ofrece Sebastián de Covarrubias en su Tesoro de la lengua castellana o española de $1611^{36}$. Asimismo, el Caballero del Febo es uno de los héroes más citados en el Quijote.

Pedro de la Sierra retomó el texto de Ortúñez de Calahorra, pero su estilo difiere bastante del de la obra de 1555, en la que no aparece ningún episodio pastoril, mientras que en la obra de Sierra el bucolismo está muy presente ${ }^{37}$. Es precisamente un episodio bucólico el que narra la historia sentimental del héroe, Claridiano, hijo del Caballero del Febo: Claridiano se enamora de una hermosa pastora, llamada Caicerlinga, cuya hermosura cautiva a todo aquel que la ve en el valle donde ella

36 "Libros de caballerías, los que tratan de hazañas de caballeros andantes, ficciones gustosas y artificiosas de mucho entretenimiento y poco provecho, como los libros de Amadís, de don Galaor, del caballero del Febo y los demás" (Sebastián de Covarrubias, Tesoro de la lengua castellana o española, eds. I. Arellano y R. Zafra, Universidad de Navarra-Iberoamericana-VervuertRAE-Centro para la Edición de Clásicos Españoles, Madrid, 2006, p. 377).

${ }^{37}$ Véase J.J. Martín Romero, Entre el Renacimiento y el Barroco. Pedro de la Sierra y su obra, Prensas Universitarias de Zaragoza, Zaragoza, 2007, pp. 27-44, donde se analizan la construcción de estos episodios y su función en el texto. Retomo aquí parte de las conclusiones de esta monografía, pero ofrezco más datos y nuevas reflexiones. 
guarda su rebaño; su belleza ha logrado fascinar incluso a reyes y emperadores que han abandonado todo para cantar su amor a la joven viviendo como pastores; pero ella da muestra de su gran honestidad al rechazar cualquier requiebro amoroso. Esta situación está claramente emparentada con el Amadís de Grecia (1530) de Feliciano de Silva, si bien Sierra transforma en parte los elementos heredados del de Ciudad Rodrigo.

En el Amadís de Grecia, Silvia vive como pastora en Tirel, ya que desconoce su origen noble. Su belleza deslumbra a todos los pastores del lugar y alrededores, a los que rechaza, pues no los considera a la altura. Allí conoce a Florisel y Garinter, que se enamorarán de la doncella. Sin embargo, sólo Florisel se mantendrá firme en su amor y adoptará un traje pastoril para estar cerca de Silvia. A pesar de todo, su amor no será correspondido, pues la doncella se enamora de oídas de Anastarax.

Las situaciones de Silvia y de Caicerlinga presentan numerosos paralelismos:

1) ambas doncellas viven como pastoras cuando, en realidad

2) son de origen noble, pero

3) se perdieron, siendo niñas, por lo que

4) desconocen su origen;

5) las dos damas se caracterizan por su gran belleza, que

G) cautiva a todos los que las contemplan, pero las damas también

7) dan muestra de su gran honestidad, pues

8) rechazan todas las propuestas amorosas de los pastores,

9) incluso rechazan a un caballero (Claridiano-Florisel), a pesar de que éste

10) había adoptado la identidad pastoril para estar cerca de la joven;

11) finalmente el caballero resulta ser un pariente de ésta (Claridiano es el hermano de Caicerlinga, mientras que Florisel es el sobrino de Silvia).

Los paralelismos resultan tan evidentes entre el episodio del Amadís de Grecia y la Segunda parte de Espejo de príncipes y caballeros que evidencian que Pedro de la Sierra conocía -e imitaba- esta obra de Feliciano de Silva.

Pero en este libro la influencia es doble, pues si por un lado deriva del Amadís de Grecia, por otro también se recuerda otro personaje de la Cuarta parte de Florisel de Niquea (1551) de Silva, Arquisidea, que vive en el valle de Lumberque. La doncella vive 
retirada ya que su belleza es tanta que llega a ser mortal. Por ello, cubre su rostro para que nadie resulte perjudicado, lo que no impide que su hermosura cautive a numerosos caballeros y pastores $^{38}$. Algunos nobles han llegado adoptar una identidad pastoril para estar cerca de la dama. Arquisidea, al igual que Caicerlinga, deslumbra por su belleza de tal forma que fuerza a reyes a convertirse en pastores; aunque Arquisidea no es una pastora como Caicerlinga, se constatan evidentes semejanzas entre este episodio de Silva y el de Sierra. El paralelismo se debe a que la belleza de una doncella lleva a los nobles a abandonar su identidad y adoptar otra nueva, la pastoril, con la intención de estar más cerca de ella. Se trata de una belleza única (Arquisidea-Caicerlinga) que es capaz de crear un mundo distinto a su alrededor, un mundo en el que todo gira en torno a la hermosura de la doncella. En ese mundo, dedicado a la contemplación de su belleza, todo lo demás pierde sentido y, por ello, no resulta extraño que reyes y príncipes abandonen su identidad -y su vida noble- para convertirse en pastores -ejemplos de vida sobria- que llevan una existencia casi contemplativa.

Cuando Claridiano encuentra a la pastora, de la que ya había oído hablar en numerosas ocasiones, no puede por menos que caer rendido ante su belleza. Decide entonces dejarlo todo por amor, no sin antes cumplir con su palabra de ayudar a dos doncellas; tras haber cumplido con su obligación caballeresca adopta la identidad pastoril y vive como pastor cantando la hermosura de Caicerlinga. Allí encuentra a dos pastores, Coridón y Galismena, que lo acogen en ese nuevo mundo (y nueva vida) para el héroe.

La historia pastoril concluye con la aparición de la violencia: Caicerlinga es raptada por el príncipe de Polismago, quien, disfrazado de pastor, había sido rechazado por la pastora. El violento rapto de Caicerlinga fuerza a Claridiano a recuperar su identidad caballeresca para liberarla. Tras derrotar al príncipe de Polismago y a varios gigantes, rescata a la pastora, que descubre entonces que Claridiano no es pastor, sino caballero. Pero cuando todo parece indicar un final feliz para la pareja, se descubre que Caicerlinga tampoco es una pastora, sino la hermana perdida de Claridiano; el héroe, al enterarse de esto,

${ }^{38}$ Véanse M. Del Pilar Villaverde Embid, Florisel de Niquea. (Cuarta parte, libro I) de Feliciano de Silva, Centro de Estudios Cervantinos, Alcalá de Henares, 2002; J.J. Martín Romero, Florisel de Niquea. (Cuarta parte, libro II) de Feliciano de Silva, Centro de Estudios Cervantinos, Alcalá de Henares, 2005. 
comprende la imposibilidad de su amor. Caicerlinga es, por tanto, una niña noble perdida que, criada como pastora, sólo recobrará su identidad y su linaje posteriormente, aunque su comportamiento honesto revelaba un origen aristocrático.

Aunque la pastora es mencionada bastante antes de su aparición, sólo cuando Claridiano la contempla se produce el enamoramiento y, por tanto, da inicio el episodio pastoril. Ese momento no se da hasta el capítulo 15 del segundo libro. El análisis de la composición de este episodio revela diversos lugares comunes propios de la literatura bucólica. En primer lugar, siguiendo el tópico de la falsa soledad, Claridiano descubre, guiado por la dulce melodía de una flauta, el lugar donde un pastor se queja por amor ${ }^{39}$. Tras dejar la flauta, este personaje -siempre observado por el caballero- comienza a cantar al son de su rabel sus penas sentimentales:

Pues pagué con el alma el bien de verte, gallarda y hermosísima pastora, y cierta de mi fe pueden hazerte las fuentes de mis ojos cada hora, ¿por qué sirve este amor de endurecerte y, despreciando al que tu nombre adora, le trata tu desdén de tal manera que no quieres que viva ni que muera? ${ }^{40}$

Se trata de una composición de reproche contra la dureza de la dama, lugar común en la poesía de nuestros Siglos de Oro, y que también resulta frecuente en la literatura pastoril ${ }^{41}$. Tras

39 "Y desviándose algo a la ribera por dexar descansar las damas, fue a dar a una parte do pudo alcançar a oír una flauta que dulcemente sonava. Y como tan agradable fuesse a sus oídos, para poder mejor gozar d'ella, se llegó más cerca, de manera que su contento gozasse de la cantinela sin ser sentido. Tanto se acercó que pudo ver quién fuesse el que la flauta tan dulcemente hazía resonar, y vido era un pastor que debaxo de un verde aliso tendido estava" (PEDro De la Sierra, Espejo de príncipes y caballeros. [Segunda parte], ed. J.J. Martín Romero, Centro de Estudios Cervantinos, Alcalá de Henares, 2003, p. 210).

${ }^{40}$ Loc. cit.

${ }^{41}$ La dureza de la dama es un tópico heredado de la Edad Media (la belle dame sans merci); véase I. Siciliano, François Villon et les thèmes poétiques du Moyen Age, Nizet, Paris, 1971; también es frecuentísimo en la poesía áurea. Para la fortuna de este tópico, véanse los comentarios de J.J. MARTín RomeRO, Entre el Renacimiento y el Barroco..., pp. 197-200. También son interesantes las opiniones de MAnuel Fernández Labrada sobre la aparición de este 
esto, aparece otro que canta la libertad de amor. Este poema servirá al enamorado para responder con otro en el que alaba el estar enamorado. Se trata de una polémica entre partidarios del amor y sus detractores, frecuente en la literatura de la época; este tipo de polémicas adoptaba en ocasiones la forma de diálogo (como en la Selva de aventuras y Febo el Troyano), pero otras veces, como aquí, se resuelve bajo la forma de una especie de justa poética, recuerdo en este caso del canto amebeo:

Herir mi amor mi pecho es escusado,

que ni quiero querer ni ser querido,

ni verme una hora alegre, otra penado,

con favores de amor o con olvido.

Essento quiero ser y libertado de los fueros y leyes de Cupido, ¡y engañe el ciego a quien le pareciere,

que a mí ya no podrá mientras viviere! ${ }^{42}$
Nunca yo sin amor tendré contento,

pues no es vida vivir sin tal cuidado,

que en sólo el gusto de mi pensamiento

el bien todo del suelo está cifrado.

Y en más estimo padecer tormento, de tal belleza siéndome causado, que, ausente de tan dulce compañía,

el descanso, la vida y alegría ${ }^{43}$.

Claridiano sigue siendo testigo secreto de la escena, que, como se ha visto, se construye siguiendo el tópico de la falsa soledad, del lamento pastoril y de la disputa sobre el amor. Toda esta escena es el preludio de la aparición de la pastora Caicerlinga, que irrumpe en la acción como una súbita visión ${ }^{44}$. A partir de aquí comienza el tormento amoroso del

tópico en Hernando de Acuña (Hernando de Acuña: italianismo y tradición en un poeta del Renacimiento español, UNED-Centro Asociado "Andres de Vandelvira", Córdoba, 1992, pp. 87-88).

${ }^{42}$ Ed. cit., p. 211.

${ }^{43} I d$. Antes de entonar esta canción, el pastor había expresado su opinión favorable al amor en estos términos: “ $¡ O$, dichoso pastor, que tanta licencia te dan Amor y tu ventura que puedas libremente publicar tu libertad, culpando mi captiverio! Publíquese a los soberanos dioses que a tal tiempo yo fuesse traído que pudiesse dezir en mis cantilenas el dulçor que con mis amores siento, que tanto gozo sentiría en saberlo dezir como tú en verte libre. ¡Ó, Júpiter poderoso, no me quites el bien que con Amor siento! Pero también te ruego me des esfuerço para poder passar mi pena” (id).

44 “...vieron que una pastora que vestida de un blanco y grosero sayal venía. Sus dorados cabellos traía sueltos detrás de las orejas, y en la mano traía un cayado labrado, con el cual guiava unas pocas ovejuelas que guar- 
héroe; no obstante, su pasión no le impedirá cumplir la palabra dada a dos doncellas -llamadas Belia y Antemisca-, llevando a una a casa de sus padres y luchando por la honra de la otra. Tras todo esto, Claridiano se muestra decidido a convertirse en pastor por amor a su pastora, lo que se producirá en el capítulo 22 de ese mismo segundo libro de la obra: "De cómo Claridiano, vencido de amores de la pastora, tomó hábito de pastor para poder mejor gozar de su delicada vista, y de lo que le avino" 45 .

Efectivamente, tal como se explica en este epígrafe, Claridiano determina abandonar sus labores caballerescas para seguir a su amada pastora también en el tipo de vida. Se trata de una evolución del personaje, que ha vivido libre de amor hasta el momento en que vio a la pastora y que, a partir de entonces, comienza a experimentar todos los males de este sentimiento. La iniciación amorosa de Claridiano está teñida, por tanto, de bucolismo. Para Claridiano, investigar ese nuevo aspecto de su vida implica despojarse de su identidad caballeresca y construir una nueva como pastor enamorado. Como tal, Claridiano se comportará de acuerdo con los tópicos propios de la literatura pastoril, entre ellos el de arbore sub quadam: arrimado a un mirto, canta al son de un instrumento sus penas de amores ${ }^{46}$; Claridiano es excelente músico y buen amador, por lo que es capaz de transmitir con su melodía sus sufrimientos ${ }^{47}$. Todo se ajusta a los lugares comunes propios de la literatura bucólica, si bien el laúd, instrumento no muy frecuente entre pastores, parece ser la nota que revela el verdadero origen noble de Claridiano, que no utiliza -frente a otros pastores literarios- ni churumbela, ni rabel ni zampoña. El efecto órfico es otro de los lugares comu-

dava. Tan hermoso traía su rostro como suele Diana mostrarse en el tiempo que más fuerça sus rayos tienen" (ed. cit., p. 211).

${ }^{45}$ Ed. cit., pp. 242-243.

${ }^{46}$ El tópico de arbore sub quadam (el pastor canta sus penas bajo la sombra de un árbol) resulta, para Vicente Cristóbal, "definitorio del género" de la poesía bucólica clásica. Véanse sus comentarios al respecto en su introd. a su ed. de Virgilio, Bucólicas, Cátedra, Madrid, 1996, p. 32.

47 “...se arrimó al mirto las espaldas y, tomando su laúd, començó a tañerle tan dulcemente que no fuera mucho, si Orfeo con su vihuela adormeció las furias infernales, don Claridiano con su laúd, no sólo las furias, pero a su reina Proserpina y antiguo Plutón pusiera en estrecho. De rato en rato sonava tan dulcemente su voz que cosa celestial juzgara ser quien lo oyera. Y como la canción le salía del coraçón con tanta pena, al doble parecía mejor" (ed. cit., p. 244). 
nes no sólo de los libros de pastores, sino de toda la literatura pastoril, recordemos las églogas de Garcilaso. Pero en el caso de Claridiano ese efecto órfico se expresa con referencias mitológicas al personaje legendario y no, como suele ser más frecuente, como apóstrofes a una naturaleza que siente en sí el dolor del poeta y músico.

Anteriormente Claridiano había sido testigo inadvertido de canciones pastoriles, dando lugar al tópico de la falsa soledad. Ahora es Claridiano, como pastor, quien cree estar solo sin estarlo, esto es, ahora es él la persona observada en el tópico de la falsa soledad: "Bien pensava el pastor que no lo oía nadie, y dos pastores atentamente escuchavan lo que así dezía" $(i d$.$) ; y$ lo que Claridiano decía no era otra cosa que su canción de amor, que esos dos pastores escuchaban disfrutando de la música y armoniosa voz del caballero:

¡Ay, rendido coraçón, qué libre, qué descuidado estavas d'este cuidado que te da tanta passión!

¿Qué desventurada suerte te ha puesto en tan grande estrecho, $<$ qne $>$ [que] no te es ya de provecho fuerça para defenderte!

Mas, ¡ay, loco!, ¿qué ventura me puede venir mayor que averme rendido amor a tan rara hermosura?
¡Ay, bellísima pastora,! ¿Qué dulce sería la <muette> [muerte], si yo mereciesse verte, aunque muriesse a la hora!

No te ofenda ser querida del que no tiene poder para dexar de querer mientras Dios le diere vida.

Y cuando el mal inhumano fuere ocasión que yo muera, ¡no sé qué más bien espera quien muere por esa mano! $!^{48}$

Pero el amor de Claridiano por Caicerlinga no es el único momento pastoril de esta obra. Además de esta transformación del héroe en pastor, Pedro de la Sierra introduce en su libro otro episodio de tintes bucólicos. Se trata de una especie de interludio lírico en la errancia de uno de los protagonistas (Eleno de Dacia). Este caballero se encuentra con pastores; algunos de ellos se lamentan por amor; el caballero, sorprendido de que también sufran penas de amor, traba con ellos una conversación sobre el sentimiento amoroso, en la que se introducen algunas composiciones poéticas. Sierra narra 
el encuentro de un modo sucinto, pero con evidentes rasgos bucólicos. En este momento, de nuevo es la música lo que descubre la presencia de los pastores, y el sentido del oído el que guía al caballero ante ellos ${ }^{49}$. Una vez más, éstos se muestran tristes, cantando su pena de amor bajo un árbol (de nuevo el tópico arbore sub quadam).

A partir de aquí el episodio (que ocupa tan sólo parte del capítulo siguiente) contiene la conversación entre estos pastores enamorados y Eleno (con tres composiciones poéticas), y una segunda conversación entre un pastor contrario al amor, llamado Tarido, que se burla de los enamorados pastores y que también se muestra en desacuerdo con el héroe. Tarido supone un contrapunto al idealizado mundo sentimental que representan los otros pastores y el propio caballero. De esa manera, el desamorado personaje pone en tela de juicio los conceptos amorosos expresados en los poemas. En primer lugar pone en duda los conceptos neoplatónicos expresados en "Amantes, ¿no es gran passión?”, conceptos amorosos relacionados con el anima animat ubi amat ${ }^{50}$ :

\section{Pastor enamorado}

Amantes, ¿¿no es gran passión y muerte muy dolorida verse partidos en vida dos cuerpos un coraçón?

\section{Pastor desamorado}

¿Qué gentil filosofía querer dar a entender que dos cuerpos están con un coraçón! Y júroos... que, por más que rebuelvas tus caramilladas razones, que no ay entendimiento humano que <enrienda $>$ [entienda] cómo dos cuerpos se goviernan con un coraçón sólo, a lo menos no quisiera ser yo el que sin coraçón estava (ibid., p. 162).

Luego se dedica a criticar la paradoja cancioneril que expresa Llena de angustia y tormento:

49 "Y dende a poco rato que avía caminado, oyó tañer un rabel pastoril que muy dulcemente sonava. Y guiando el cavallo para allá, fue a dar a donde estavan unos pastores tendidos en tierra con el semblante triste a do debaxo de una noguera la siesta dexavan passar" (Segunda parte de Espejo..., p. 160).

${ }^{50}$ Sobre este tópico véase GuIllermo Serés, La transformación de los amantes. Imágenes del amor de la Antigüedad al Siglo de Oro, Crítica, Barcelona, 1996. 
Pastor enamorado

Llena de angustia y tormento queda la triste memoria cuando de pena o de gloria le viene algún pensamiento (id.).

\section{Pastor desamorado}

Pues atendamos a las razones de estotro compañero, rebolviendo pena con gloria y gloria con pena como si fuessen migas con leche $(i d$.$) .$

Tarido demuestra una gran insensibilidad ante los sentimientos de sus compañeros, y se presenta como un ser obtuso incapaz de comprender lo que éstos cantan ("Y si mucho porfiassen, me haría entender lo que no fue"). El héroe, ante su necios comentarios, y a pesar de su dolor por la muerte de su amada, no puede por menos que reír.

La figura de Tarido, como la del pastor desamorado de Febo el Troyano, se vincula con la de Mordaqueo, personaje que aparece en varias de las obras que forman el ciclo amadisiano compuestas por Feliciano de Silva. Mordaqueo es un pastor rústico que se opone a Darinel, pastor enamorado cuyos sentimientos por la hermosa Silvia lo han transformado en un ser mejor que se expresa como un educado cortesano. Frecuentemente, Mordaqueo y Darinel se dedican a hablar, ante los miembros de la corte, sobre el amor, y, ante las exquisitas explicaciones del amor por parte de éste, aquél hace reír a todos con sus comentarios zafios ${ }^{51}$.

Por tanto, Sierra (como hizo Corbera en su Febo el Troyano) introduce un interludio pastoril aderezado con una tópica discusión sobre el amor. El duelo dialéctico entre pastores enamorados y desamorados parece percibirse como un lugar común, que también se relaciona con la importancia del diálogo en el quinientos español ${ }^{52}$.

Pero esta discusión no es la única que Sierra introduce en su texto, pues también en el episodio pastoril de Claridiano se encuentra otra, pero esta vez no sobre el amor, sino sobre el valor de la mujer. Dos de los compañeros de Claridiano en su vida pastoril, los hermanos Coridón y Galismena, muestran opiniones encontradas sobre la mujer. Galismena lamenta que todo el valle esté poblado de pastores que olvidan sus obligaciopp. 69-74

${ }^{51}$ Véase Cravens, Feliciano de Silva y los antecedentes de la novela pastoril...,

${ }^{52}$ Véase Jesús Gómez, El diálogo en el Renacimiento español, Cátedra, Madrid,1988, así como El diálogo renacentista, Laberinto, Madrid, 2000. 
nes y dejan morir de hambre a su ganado a causa del amor a una pastora. En ese momento Galismena afirma la superioridad del varón frente a la mujer ${ }^{53}$. Estas palabras enfurecen a Coridón, quien afirma que, de haberlo dicho otra persona, le haría pagar caro sus palabras. Claridiano impide que la discusión se vuelva más violenta, de igual manera que habían hecho los caballeros en Febo el Troyano. La discusión sobre el valor de la mujer era un tema frecuente en la literatura del siglo XVI, pero también en el siglo anterior (recordemos las obras del Tostado, la Cárcel de amor de Diego de San Pedro, el Tratado en defensa de virtuosas mujeres, de Diego de Valera, el Libro de las claras e virtuosas mujeres de don Álvaro de Luna, o el Triunfo de las donas de Juan Rodríguez del Padrón $)^{54}$. Sierra recoge este tema, pero de manera sucinta, sin extenderse en un debate académico o duelo dialéctico como hacen los personajes de Febo el Troyano (y, por tanto, de la Selva de aventuras). El aragonés prima la narración sobre la digresión, y se limita a ofrecer pinceladas de estos grandes temas de la época; y lo hace siempre al servicio de la narración, nunca para interrumpirla.

Sin embargo, además de los episodios pastoriles mencionados, la influencia de lo pastoril se detecta en otros elementos que, aunque derivados de obras pastoriles, se reescriben como materia caballeresca. Así, Eleno de Dacia sufre por haber sido rechazado por su prima. Esta historia de amor no es sino una reescritura narrativa de parte de la Segunda Égloga de Garcilaso de la Vega ${ }^{55}$. Es más, en una ocasión, Eleno canta un poema que deriva, de forma casi literal, de esta obra garcilasiana.

Por si fuera poco, también encontramos ecos de la obra de Jorge de Montemayor en la historia sentimental de Eleno de Dacia. Este héroe olvida su amor por su prima para enamorarse de otra hermosa doncella, Lidia. Tampoco esta vez será afortunado, pues esta dama ama a otro caballero. Ella, a su vez, también es rechazada por este otro caballero, por lo que muere de amor. Y es precisamente cuando la doncella se

53 “...no ensalces a Caicerlinga tanto, que por ella no sólo deseches todas las pastoras, pero amengües todos los pastores de la ribera. Claro es que aunque el merecimiento de Caicerlinga sea mucho, que por ser mujer no llega a $<$ tanta $>$ [tanto] como el del menor pastor de nuestra habitación, pues le basta ser varón” (Segunda parte de Espejo..., ed. cit., p. 245).

${ }^{54}$ Véase supra, nota 23.

${ }^{55}$ Véase J.J. Martín Romero, "Garcilaso de la Vega como objeto de imitación...”. 
halla al borde de la muerte cuando, en sus últimas palabras, se escuchan las de Montemayor. Sierra, para componer este último diálogo entre la moribunda Lidia y el rechazado Eleno, acude a la obra del portugués, en concreto al poema narrativo, Historia de Alcida y Sylvano, una composición en octava real que narra la desdichada historia de amor de estos dos pastores. Pues bien, son precisamente las palabras entre Alcida y Silvano las que escuchamos (con un cierto grado de transformación que no oculta su fuente) en boca de Eleno de Dacia y de Lidia $^{56}$.

En conclusión, en la obra de Sierra los elementos pastoriles suponen un aspecto muy relevante de la narración. El aragonés, siguiendo la tendencia del género, insertó diversos elementos bucólicos en su obra caballeresca; por una parte, un interludio lírico en la errancia de Eleno de Dacia, y, por otra, todo un episodio pastoril que supone la iniciación amorosa del protagonista, Claridiano. Y, además de esto, lo pastoril se filtra en otros muchos momentos e impregna prácticamente todos los aspectos sentimentales de la Segunda parte de Espejo de príncipes y caballeros.

ROSIÁN DE CASTILLA (1586), DE JoAQuín Romero de CEPEdA

La historia de Rosián de Castilla de Joaquín Romero de Cepeda vio la luz en las prensas lisboetas de Marcos Borges en 1586, seis años después de la aparición de la Segunda parte de Espejo de príncipes y caballeros de Pedro de la Sierra. Rosián de Castilla es una obra que se singulariza dentro la producción caballeresca ${ }^{57}$. Rompe con muchos de los tópicos propios del género y asume realmente una función didáctica, no sólo bajo la forma de glosas -tal y como ya hizo Garci Rodríguez de Montalvo en el Amadís de Gaula- sino con la inclusión de capítulos enteros a modo de

${ }^{56}$ Martín Romero, Entre el Renacimiento y el Barroco..., pp. 187-188.

${ }^{57}$ La obra ha sido analizada por E.J. SALES DAsí, "Una crónica caballeresca singular del quinientos: el Rosián de Castilla", en Fechos antiguos que los cavalleros en armas passaron. Estudios sobre la ficción caballeresca, ed. J. Acebrón Ruiz, Edicions de la Universitat de Lleida, Lleida, 2001, pp. 151-190. Por su parte, sobre la figura femenina en esta obra, véase I. RoMERo TABAREs, "Modelos de mujeres en los libros de caballerías hispánicos. El Rosián de Castilla”, en ibid., pp. 191-215. 
tratados dedicados a diversos temas, entre los que destaca las normas de comportamiento de la mujer casada ${ }^{58}$.

Esta obra narra la biografía caballeresca de Rosián de Castilla, quien no sólo debe derrotar monstruos, serpientes, osos, lagartos y brujas, sino que también ha de evitar los peligros contra su virtud: el héroe ha de triunfar sobre la soberbia y la lujuria, entre otros pecados, para asumir una identidad caballeresca propia. Su errancia se convierte en una especie de peregrinación en la que se produce un proceso de aprendizaje y evolución psicológica a partir de las diversas pruebas que tiene que superar.

El proceso de aprendizaje también está jalonado por encuentros con diversos personajes; entre quienes está Bricia. El encuentro entre el héroe y esta dama se compone siguiendo los lugares comunes de la literatura pastoril. Se narra en el capítulo 13 de la primera parte de este libro: Rosián llega a una agradable floresta y "pareciéndole el lugar ameno y deleytoso para refrescarse, apeándose de su cauallo se assienta junto a vna fuente que en medio de mucha diuersidad de árboles, de la solícita naturaleza produzidos, estendía sus arroyuelos por todos aquellos campos" 59 .

El escenario bucólico aparece descrito con eficacia, pero también con la sobriedad estilística propia de Romero de Cepeda, que evita la complicación sintáctica, los hipérbatos forzados y los juegos de palabras. Romero de Cepeda no parece querer deslumbrar con su prosa, si bien tampoco cae en la sequedad de estilo. Encontramos todos los elementos necesarios: "lugar ameno y deleytoso", "vna fuente", "diuersidad de árboles", "arroyuelos". El escenario crea unas expectativas pastoriles que serán satisfechas. Así, en ese lugar "tomando del agua para refrescar las manos y rostro... oyó a vn lado de la fuente entre vnos árboles vna boz tan suaue y de tanta melodía que, casi suspenso y eleuado, con mucha atención atendiendo, vio que dezía desta

${ }^{58}$ Se encuentra en el capítulo 2 del texto. Véase JoAQuín Romero DE Cepeda, La historia de Rosián de Castilla, ed. R. Arias, CSIC-Instituto "Miguel de Cervantes", Madrid, 1979, pp. 8-12. Pero son varios los caps. de esta obra dedicados íntegramente a aspectos didácticos: además del mencionado, los capítulos 4, 5, 6, 7, 8 y 10 estructuran una serie de enseñanzas. Sobre los aspectos didácticos y morales en los libros de caballerías, véase José Julıo Martín Romero, "Buenas dotrinas y enxemplos", Memorabilia, 2004-05, núm. 8 (http://parnaseo.uva.es).

${ }^{59}$ El episodio de Bricia ocupa los capítulos 13 y 14 (ed. cit., pp. 32-39; la cita en p. 33). 
manera..." $(i d)$. Rosián escucha, sin ser visto, una canción que atrae su atención. La canción ("Dexame, tristes cuydados") se estructura atendiendo a la contraposición entre un pasado feliz y un presente desdichado; se trata de un doloroso recuerdo del bien perdido ("ya pasó quien ser solía") y un lamento ante una triste situación actual ("Agora todo ha de ser / pena, passión y agonía. / Ya passó quien ser solía”). Este escenario y esta canción preparan la situación anímica, el pathos, del episodio: todo transmite una desdicha terrible. Esto se confirma cuando el autor alude a la impresión que dicha canción causa en Rosián ${ }^{60}$. La música cumple la función de proporcionar unos elementos que despiertan el interés del lector, los "ynumerables suspiros acompañados de muchas lágrimas y solloços” cuya causa, desconocida por el momento, se contará seguidamente. Como puede verse, se trata del tópico de la falsa soledad; así, siguiendo la pista sonora, Rosián encontrará el origen de la música hasta dar con un nuevo personaje: "con desseo de conocer la persona que tan suauemente cantaua, se fue hazia donde le pareció que venía la boz. Y a poco espacio halló vna graciosíssima pastora de que no poco fue admirado, ansí de su hermosura y gracia como de su tristeza y soledad" ( $i d$.$) . Se presenta de esta manera el nuevo$ personaje, esa "graciosíssima pastora", cuya situación y belleza admira al héroe del libro, así como a su lector, que tendrá que esperar hasta el capítulo siguiente para conocer su historia y la explicación de los suspiros y llantos de la pastora. Rosián se presenta ante ella con corteses palabras; el caballero la trata como noble, pues no puede creer que sea una humilde pastora ${ }^{61}$.

La sospecha de que el personaje no sea un pastor sino persona de más alto linaje es uno de los tópicos que la temática pastoril presenta en su aparición en los libros de caballerías, como ya señalé. Así ocurre en el Olivante de Laura y en la Segunda parte

60 "Tan admirado estaua Rosián de la suauidad de la boz como de la tristeza con que esta canción era cantada, ansí por las palabras que en ella se contenían como por los estremos de tristeza que acabando de cantar vna hermosa pastora hazía, dando ynumerables suspiros acompañados de muchas lágrimas y solloços" (ed. cit., p. 34).

61 "Grande es la admiración, hermosa pastora, que me ha puesto ansí vuestra suauidad de música como vuestra tristeza; y con vuestra licencia desseo saber la causa de tantos estremos, porque de qualquiera cosa en vuestro daño recibiría yo singular pena, como, al contrario, de todo vuestro bien tendría todo contentamiento. Ansí que ruégoos mucho me contéys la estrañeza de vuestra vida, que según vuestra dispusición esse hábito no me parece lo recebistes en la cuna" (ed. cit., p. 35). 
de Espejo de príncipes y caballeros, donde se encuentra el tópico del héroe transformado en pastor, si bien no sucede así en Febo el Troyano, ya que en esta obra no encontramos el motivo del caballero con disfraz pastoril. Rosián parece comprender que la doncella no ha sido siempre pastora ("según vuestra dispusición esse hábito no me parece lo recebistes en la cuna"); el traje pastoril no encubre la nobleza de la dama, tal y como sucedía con Olivante y Silvano, en la obra de Torquemada, o con Claridiano, en la de Pedro de la Sierra.

Las sospechas de Rosián se verán confirmadas cuando la dama, llamada Bricia, cuente su historia. Enamorada de un mancebo llamado Albinio, se veía con él secretamente a través de un agujero en sus habitaciones, que eran contiguas. La clandestina relación sentimental se mantuvo hasta que fueron descubiertos por la familia de la dama, cuyo hermano desafió a Albinio. Durante la pelea ambos quedaron heridos. Albinio "con buen auiso se auía recogido al reyno lusitano", de forma que la dama quedaba "sin esperança de velle". Por su parte, la doncella huyó de la furia de sus parientes y de la deshonra pública; para ello decidió abandonar su vida y adoptar una nueva identidad como pastora, alejada de su tierra y de su familia ${ }^{62}$.

Lo que se iniciaba como una historia pastoril termina siendo una historia de amor urbano centrado en la honra. No hay problemática de desamor, sino amores clandestinos que concluyen de forma desdichada, destruyendo la identidad de Bricia. La situación pastoril de la dama se contempla como un castigo a su comportamiento inadecuado, su vida como pastora es una "vida sin esperança de contentamiento", en la que sólo cabe esperar "la temerosa muerte".

Frente a lo que hemos visto hasta ahora, en el Rosián el propósito de la inclusión de este episodio es reflejar los peligros de los amores deshonestos. No se trata de la biografía sentimental del héroe siguiendo un concepto idealizado del amor. Como resultado de este encuentro, el protagonista determina evitar enamorarse a toda costa: "Y ansí propuso en su coraçón de no

62 "Mas temiendo la yra de mis padres, el afrenta de mi hermano y bozería del pueblo, determiné (dexando los regalos paternales) seguir al mi Albinio en los trabajos; y mudando el hábito de dama en pastora, guardo aquí este ganado en compañía de algunas pastoras que en esta tierra lo tienen por costumbre, en cuya vida sin esperança de contentamiento espero la temerosa muerte" (ed. cit., pp. 38-39). 
poner en ninguna muger su affición, porque la libertad del hombre es el mejor thesoro del mundo". Por tanto, este episodio forma parte de ese proceso de aprendizaje que va moldeando la psicología del personaje. De esta forma, se comprende que, posteriormente, Rosián cante en un soneto su deseo de no caer en las redes del amor:

¿Quán lleno de contento y alegría

El coraçón de amor libre se siente!

No le da pena el verse estar ausente,

No muere por presencia cada día.

No llora el bien que pierde, ni se fía

De la esperança vana que consiente.

No le haze morir el acidente.

No tiene el no querer por couardía.

Aparejado a sufrir lo que viniere,

Contento con el bien o con el daño,

Fortuna tiene el modo o la medida.

No teme de su suerte algún engaño,

Ni menos se recata de la vida,

Porque es sola razón la que ama y quiere ${ }^{63}$.

Este elogio del estado libre de amor se corresponde con otras composiciones que hemos encontrado en Febo el Troyano o en la Segunda parte de Espejo de principes y caballeros, y que encontraremos en obras como la Tercera parte de Espejo de príncipes y caballeros. Se trata del reflejo en verso de la controversia en favor y en contra del amor. Rosián, frente a otros héroes caballerescos, se presenta como un claro partidario de la libertad de amor, cuyos efectos negativos no ha conocido sino por terceros, pero que en ningún caso le atrae experimentar. Si bien posteriormente Rosián se enamorará de Calinoria, su historia amorosa (por lo demás siempre honesta y sin matrimonio secreto alguno) no será nunca el motor de las hazañas del héroe, que se aparta así de las convenciones genéricas amadisianas. De esta manera, el episodio de Bricia cumple la función de ejemplificar los riesgos del amor y los desvaríos que provoca en el comportamiento humano, de forma que Rosián aprenda esa lección vital y evolucione en su proceso de mejora, fin último de su errancia, que en ocasiones se denomina, significativamente, peregrinación ${ }^{64}$.

${ }^{63}$ Ed. cit., p. 45.

${ }^{64}$ Esto acerca el Rosián a la Selva de aventuras, donde el personaje también va creciendo y madurando en su peregrinación. 
En cualquier caso, la historia de Bricia recoge parte de los tópicos propios de la temática pastoril, pero no propone una historia de amor bucólica, pues los personajes no son pastores y su comportamiento sentimental tampoco es el convencional en este tipo de ficción.

Frente a los episodios o interludios pastoriles insertos en los otros libros de caballerías, el episodio de Bricia comparte la adopción de la vida pastoril por parte de un personaje que no nació pastor. Pero ese personaje es una dama que huye, y no un caballero que desee acercarse más a su amada. La historia de Bricia se aparta de los episodios pastoriles que aparecen en otras obras caballerescas y se acerca a la figura de Felismena, en La Diana de Jorge de Montemayor, que adoptó la misma decisión que Bricia ante sus desdichados amores:

Pues como no bastase la diligencia que en saber del mi don Felis se puso, que no fue pequeña, yo determiné ponerme en este hábito en que me veis, en el cual ha más de dos años que he andado buscándole por muchas partes, y mi fortuna me ha estorbado hallalle... ${ }^{65}$.

Por tanto, Felismena -al igual que Bricia- se encuentra disfrazada de pastora. Aunque la actitud activa (y combativa) de Felismena es bien distinta del comportamiento casi nihilista adoptado por Bricia, ambas se acogen al anonimato que proporciona el disfraz pastoril para buscar alivio a sus penas: Felismena buscando a su amado Felis, Bricia huyendo de la deshonra. Ambas narran su historia desde la tristeza, tristeza que sólo desaparecerá en el caso de Felismena, pues Romero de Cepeda, como se ha dicho, no vuelve a hablarnos de Bricia.

El personaje de Felismena hubo de impresionar a Romero de Cepeda, a juzgar por el reflejo que de él se encuentra en su producción literaria. Además de la historia de Bricia, encontramos ecos aún más claros del personaje de Montemayor en el teatro de este autor. En concreto, en su Comedia salvaje, una de las heroínas, llamada Lucrecia, se disfraza de pastora y se enfrenta a dos salvajes, tal como Felismena hace en La Diana ${ }^{66}$.

${ }^{65}$ Jorge de Montemayor, La Diana, ed. A. Rallo, Cátedra, Madrid, 1999, pp. 210-220.

${ }^{66}$ Véanse los comentarios de Reyes Narciso García-Plata a su edición de la Comedia salvaje en J. Romero de CEPEDA, Teatro, Universidad de Extremadura, Cáceres, 2000, p. 203, n. 203. 
Lucrecia también finge ser pastora ("Soy una pobre pastora / criada en estas montañas / que con fieras alimañas / tengo guerras cada hora" ${ }^{67}$ ), pero finalmente se descubre que no es tal, sino la noble Lucrecia, hija de Albina, y consigue el amor de su amado Anacreo.

Por otra parte, el episodio pastoril del Rosián de Castilla también recoge la controversia a favor y en contra del amor. Pero, de nuevo, el héroe adopta la posición contraria a la que se puede esperar de un héroe caballeresco, pues no defiende el estar enamorado, sino el hecho de no estarlo.

Los efectos del amor también aparecen en otra obra de Romero de Cepeda, la Comedia metamorfosea, su única incursión conocida en el teatro pastoril. Sin embargo, esta comedia no deriva tanto de la tradición de Juan del Encina como de la del pastor enamorado, más cercano al aparecido en La Diana.

La Comedia metamorfosea narra los amores no correspondidos de diversos pastores. Cada personaje ama a otro que, a su vez, ama a otro distinto, de forma que nunca encuentran satisfacción. A partir de la segunda jornada los sentimientos de todos ellos cambian, pero de nuevo se produce ese encadenamiento de amores que conlleva que nadie sea correspondido ${ }^{68}$. Entre esos pastores, siempre hay uno que se encuentra libre de amor. Inicialmente se trata de Medoro, que rechaza a Belisena. Pero en un determinado momento, Medoro se enamora de Belisena cuando ya es demasiado tarde, porque ésta ya no lo quiere. Por su parte, a partir de la transformación colectiva de sentimientos que se produce en la segunda jornada de la comedia, una pastora, llamada Albina, se da cuenta de los peligros de amor y decide dejar de amar. Albina es, al final de la comedia, el personaje desamorado, de igual forma que Medoro lo era al inicio de la obra.

Las palabras iniciales de Medoro en favor de la libertad y en contra de estar enamorado son muy significativas:

¡Oh libertad de razón, quán gran tesoro es tenerte, quán gran bien es conocerte!

¿Qué suprema presumpción es por ninguno perderte!

${ }^{67}$ Comedia salvaje, en ibid., p. 205.

${ }^{68}$ Resulta inevitable pensar en la cadena de amores en La Diana, ed. cit., p. 149. 


$$
\begin{aligned}
& \text { ¡Oh quánto estimo mi hado, } \\
& \text { pues voy tan lexos de amor, } \\
& \text { quanto libre de cuidado, } \\
& \text { y tan sin pena y dolor } \\
& \text { como de amor olvidado! }^{69}
\end{aligned}
$$

El no estar enamorado implica, según este poema, "libertad de razón”. Recordemos que el poema cantado por Rosián determina la alegría del que está libre de amor: "iQuán lleno de contento y alegría / El coraçón de amor libre se siente!”, y ello se explica "porque es sola razón la que ama y quiere". Recordemos que, tras haber conocido a Bricia, Rosián decide no caer en las redes del amor, "porque la libertad del hombre es el mejor thesoro del mundo", idea que repite Medoro: "¡Oh libertad de razón, / quán gran tesoro es tenerte!”. La ideología de Romero de Cepeda no cede ante las presiones de los tópicos literarios, y se mantiene constante en su producción literaria.

En definitiva, este autor no contempla con muy buenos ojos el amor, que no se concibe en su libro de caballerías como motor de la acción heroica, sino como tentación (y se vincula a la lujuria: Belarina) o al amor casto (y tiene por objeto el matrimonio: Calinoria). La historia de Bricia cumple la función de advertir a Rosián de los peligros del amor no dominado por la razón.

La actitud de Romero de Cepeda con respecto al amor recuerda bastante a la de Fernando de Rojas en La Celestina, no en vano la Comedia salvaje está claramente vinculada con la tradición celestinesca, como se observa ya desde las indicaciones en su título:

COMEDia SALVAJE, en la qual, por muy delicado estilo y artificio, se descubre lo que de las alcahuetas a las honestas doncellas se le sigue, en el proceso de lo qual se hallarán muchos avisos y sentencias ${ }^{70}$.
Síguese la Comedia o Tragicomedia de Calisto y Melibea, compuesta en reprehensión de los locos enamorados que, vencidos en su desordenado apetito, a sus amigas llaman y dizen ser su dios. Así mismo fecha en aviso de los engaños de las alcahuetas y malos y lisonjeros sirvientes ${ }^{71}$.

${ }^{69}$ Comedia metamorfosea, en J. Romero de CePedA, op. cit., p. 214.

${ }^{70}$ Ed. cit., p. 133. Véanse también los comentarios de su editor, R.N. García-Plata, en la n. 1 a esa misma página, así como su introd., pp. 35-84.

${ }^{71}$ Fernando de Rojas, La Celestina. Comedia o Tragicomedia de Calisto y Melibea, ed. P.E. Russell, Castalia, Madrid, 2002, p. 221. 
Por tanto, no ha de sorprender que Romero de Cepeda se aleje del concepto de amor de los libros de caballerías, así como de tópicos como el matrimonio secreto. Asimismo, tampoco ha de sorprender que Bricia, enamorada clandestinamente, haya de sufrir por su pecado y por no haberse comportado de forma honesta, tal y como se esperaba de ella. Ella y su pasión han sido las causantes de las heridas de su hermano y del sufrimiento de sus padres. Por tanto, se ve desposeída de todo, incluso de su identidad, por lo que ha de adoptar la de una humilde pastora. El desenlace de la historia no se cuenta, porque no es necesario, Romero de Cepeda ya ha demostrado lo que quería, los efectos negativos del amor.

Tanto en la tradición celestinesca, como en el teatro pastoril y en los libros de caballerías, Romero de Cepeda expresa su idea de que el amor es causa de trastornos y sufrimientos. El amor aleja al hombre de la razón y la alegría. La alegría sólo se consigue mediante la razón, que no puede estar oscurecida por las obcecaciones amorosas.

Para concluir, la función y el sentido del episodio de Bricia contrastan con los que aparecen en obras caballerescas previas, si bien el encuentro del héroe con la dama se conforma con los tópicos propios del lamento pastoril y la falsa soledad, y recuerda en parte episodios de La Diana de Montemayor.

\section{TERCERA PARTE DE ESPEJO DE PRÍNCIPES Y CABALLEROS (1587), de Marcos MarTínez}

El alcalaíno Marcos Martínez publicó en 1587 una continuación del ciclo de Espejo de príncipes y caballeros. Se trataba de la tercera parte del ciclo y, al igual que la edición príncipe de la segunda parte, salió de las prensas complutenses de Juan Íñiguez de Lequerica. Marcos Martínez abandonó la austeridad de Diego Ortúñez de Calahorra, autor de la primera parte del ciclo, y compuso una obra más cercana (a pesar de las diferencias evidentes) a la de Pedro de la Sierra. Al igual que éste, Martínez introdujo elementos pastoriles en su obra, ya desde el prólogo. El narrador cuenta cómo en una ocasión se pierde caminando por agradables y amenos lugares: "cercado de pomposos álamos, donde las hermosas avezillas con sus deleitosos cantos el señalado día celebravan, oyendo las cristalinas aguas hazer un sonoroso ruido con su concertada lu- 
cha"72. Cuando, tras la caminata, se dispone a descansar, escucha una canción entonada al son de un rabel. La música delata la presencia de un personaje, un pastor (llamado Polio) que, en compañía de una hermosa pastora (Delia), se queja de su rechazo. Una vez más, el tópico de la falsa soledad es el recurso que se utiliza para presentar un personaje y una situación pastoriles. De nuevo, ese tópico viene acompañado del lamento de amor, expresado en la canción ("Por esso mi pastora no estés fuerte, / basten ya los tormentos que me has dado, / en prolongar mi gloria con ausencia"). Se trata de un lamento de amor que se pronuncia (en este caso, se canta) en medio de una naturaleza idealizada, como suele ser frecuente, pero aquí, además, se contempla un diálogo entre ese pastor y la pastora que lo rechaza. Ella responde con un soneto en que pide a su amante que, si la quiere, pruebe la aventura de la cueva de Anglante. Como Polio es consciente de que probar esa aventura significa perder la vida, le reprocha su actitud e incluso llega a intentar forzarla ("Y en diziendo estas razones de un ligero salto se puso con la hermosa Delia, pensando rematar su dudoso intento").

El pastor desea el cuerpo de su amada; estamos lejos del amor neoplatónico que habíamos visto en otros episodios pastoriles de los libros de caballerías. Polio actúa por instinto y no duda en utilizar la violencia. Si bien a esas alturas los libros de pastores habían comenzado a introducir aspectos menos idealizados, los elementos pastoriles en los libros de caballerías, como hemos visto, habían mantenido el carácter elevado del amor bucólico. Quizá tan sólo Romero de Cepeda había introducido elementos más humanos, por su evidente intención moralizante, y tampoco había llegado a los extremos de recrear un intento de violación por parte de un pastor enamorado. De esta manera, este episodio pastoril de la Tercera parte de Espejo de principes y caballeros se aleja de la tendencia genérica (caballeresca), si bien parece acercarse a algunos de los libros de pastores. La violación no tiene lugar porque Delia huye y el autor detiene a Polio para impedir la injuria. Polio, incapaz de soportar sus sentimientos, muere en brazos del narrador, tras despedirse del entorno natural:

${ }^{72}$ Marcos Martínez, Tercera parte de Espejo de príncipes y caballeros, ed. A. Campos García Rojas, Centro de Estudios Cervantinos, Alcalá de Henares (en prensa). Agradezco al profesor Campos, quien generosamente me ha proporcionado su transcripción del texto. 
Adiós os quedad campos, y no os pese perder vuestro contino compañero. Adiós frondosos povos, adiós hermosas flores, adiós resonante Eco, a quien comunicar solía mis amorosas quexas. Adiós aguas cristalinas, adiós deleitosas aves, pues al son de vuestro canto solían mis penosos cuidados tomar algún alivio. Adiós ganado, buscad de oy más otro pastor, que con más cuidado os apaciente en la más sabrosa yerva. Adiós, hermoso rabel, adiós gaván polido aliviador de mi continuo cansancio ${ }^{73}$.

Será el autor quien se encargue de enterrar al desdichado pastor y de grabar en la corteza de un sauce un poema que recordara su triste muerte ${ }^{74}$. El autor hace un par de menciones que dan más detalles sobre Delia. En primer lugar, se afirma que Polio quería "adulterar el noble Tolomeo esposo de la agraciada Delia" y, luego, hablando con este pastor, el autor le recrimina que quisiera "de tan abominable modo injuriar la bella pastora, siendo con otro casada". En realidad, nada han dicho a este respecto los pastores, lo que parece indicar que el narrador conocía a los personajes, ya que de otro modo no sería posible que tuviera esa información. Quizá este prólogo pastoril sea la recreación de una historia sentimental que Marcos Martínez conociera, esto es, que fuera una narración à clef, como se ha interpretado La Diana (atendiendo a las indicaciones de su autor) o como hay que entender otros libros de pastores de carácter autobiográfico ${ }^{75}$.

En cualquier caso, este episodio pastoril funciona como introducción a la aventura de la cueva de Anglante, en la que

${ }^{73}$ Estas palabras recuerdan la segunda égloga garcilasiana: “;Oh lobos, oh osos, que por los rincones / destas fieras cavernas ascondidos / estáis oyendo agora mis razones!, /quedaos a Dios, que ya vuestros oídos / de mi zampoña fueron halagados / y alguna vez d'amor enternecidos / Adiós, montañas; adiós, verdes prados; / adiós, corrientes ríos espumosos" (GARCilaso de la Vega, Poesías castellanas completas, ed. E.L. Rivers, Castalia, Madrid, 1992, p. 154).

74 "Bien puede rebolver su curso el cielo / [aviendo] las naciones trastocado / [haziendo] rebolver a lo humanado / con cuanto está criado en el suelo. / Primero se verá caliente el yelo, / que se viere jamás en algún prado / algún pastor tan firme enamorado / como el infeliz Polio de Sincelo. / Aqueste de su Delia enamorado, / viendo su coraçón como diamante / por tener su esperança ya perdida, / en este gran pradal del sabio Anglante, / a la terrible muerte se ha entregado, / sin que fuesse de sí proprio homicida".

${ }^{75}$ Véase J. Subirats, “La Diane de Montemayor, roman à clef?”, en Études Ibériques et Latinoamericaines, Presses Universitaires de France, Paris, 1968, pp. 105-118. También J.B. Avalle-Arce, La novela pastoril española, pp. 141-174. 
el autor ha de penetrar para recuperar los manuscritos que cuentan la historia de los héroes. La aventura de la cueva de Anglante supone la narración ficticia de cómo se consiguieron las volúmenes que relatan los hechos heroicos de los protagonistas del texto. El origen de este motivo se encuentra en las Sergas de Esplandián, en el momento en que el autor narra cómo Urganda la Desconocida lo instó, tras hacerlo visitar el mágico lugar en que los héroes estaban encantados, a continuar con su labor literaria. También lo encontramos en los prólogos del Belianis de Grecia (1547), del Olivante de Laura (1564) o de Febo el Troyano (1576). Se trata, por tanto, de un lugar común en los prólogos de libros de caballerías ${ }^{76}$. Además, la aventura de la cueva de Anglante abandona todo rastro pastoril para ser una hazaña mágico-bélica propia de la literatura caballeresca. Por tanto, la historia de Polio y Delia sirve meramente de inicio o presentación de una aventura típicamente caballeresca.

Por otra parte, aunque el autor ensalce el fuerte amor de Polio, queda fuera de toda duda que no se trata de un amor idealizado ni cercano al neoplatonismo, sino de una fuerza casi animal que lo trastorna; se trata más bien de la enfermedad de amor, el amor hereos.

Otro de los momentos en que reaparece la temática pastoril es el capítulo 27 del tercer libro de la obra. En ese capítulo se narra cómo los héroes encuentran a un pastor que canta y se lamenta por amor. La estructura del encuentro coincide con el lugar común de la falsa soledad. De esa manera, los héroes descubren la presencia del pastor a través del oído:

Poco fue el sueño, que una suavíssima voz se le quitó, acompañada de lastimosos sospiros. A la par despertaron los dos griegos... Assí se levantaron y, poniendo los yelmos con sus escudos en los braços por si huviesse necessidad, se fueron passo a la parte do se oía la voz, que entonces acabava. Llegaron a un pequeño campo que allí se hazía entre los pomposos árboles y vieron un pastor de la más

${ }^{76}$ M.I. Muguruza Roca vincula este motivo en las Sergas de Esplandián, el Olivante de Laura y la Tercera parte de Espejo de príncipes y caballeros, en "Sobre el prólogo de Don Olivante de Laura de Antonio de Torquemada”, en Evolución narrativa e ideológica de la literatura caballeresca, ed. M.E. Lacarra, Universidad del País Vasco, Bilbao, 1991, pp. 127-144. Por su parte, Claudia Demattè lo analiza en Febo el Troyano: "«Así muchas vezes los ojos me alimpiaua, más veya siempre ser así»: del prólogo de Febo el Troyano a la cueva de Montesinos”, en Fechos antiguos que los cavalleros en armas passaron. Estudios de ficción caballeresca, ed. J. Acebrón Ruiz, Universidad, Lleida, 2002, pp. 217-229. 
hermosa diposición del mundo, tan hermoso que al que guardava las cabras de Admeto tornara en verle invidioso. Era, al parecer de pequeña edad; tenía en las manos una chirumbela, a cuyos dexos él dava del alma tristes a los robles testimonio.

Los héroes escuchan una voz que se convierte en una especie de rastro sonoro que los lleva al lugar donde encuentran a un personaje al que espían: un pastor de gran hermosura que, además, tañe una "chirumbela", instrumento claramente pastoril. Los héroes no dudan de que éste ha de ser un pastor enamorado ("el que canta, a mi parecer, vive de ser enamorado"). Todo está teñido de bucolismo: naturaleza ("un pequeño campo que allí se hazía entre los pomposos árboles”), música ("una chirumbela”) y amor ("¡O Amor, y cuántas veras has provado en mí lo que puede tu riguroso braço!”) alrededor de un pastor de gran hermosura; por si fuera poco, en este episodio tampoco falta la canción de amor ${ }^{77}$. La descripción de este pastor se corresponde con la figura del pastor idealizado: enamorado, excelente músico y de sentimientos elevados. Sin embargo, el mundo caballeresco de Marcos Martínez no parece acoger, como hizo Pedro de la Sierra, esta figura, y pronto se deja intuir que este personaje no es realmente un pastor, al igual que Silvano en el Olivante de Laura. En efecto, uno de los héroes griegos duda de la identidad pastoril del personaje: "No me creáis, príncipe de Grecia -dixo Claramante-, si fuerça de amor no le ha hecho tomar este disfraçado hábito, porque, aunque aya bizarros pastores por los campos, esta ternura que muestra da a entender no aver guardado ganado, sino que ha sido servido". Inmediatamente después la canción que entona este personaje indica que el caballero no se equivoca, y que el joven no es en realidad tal pastor, sino que se trata de un disfraz ("Pena me es el andar de gente en gente ( con disfraçado ser peregrinando"). Tras haber escuchado la canción y las lamentaciones del pastor, los héroes deciden darse a conocer ("Y con esto hizieron algún ruido, para que el descuidado pastor entendiese su venida"). Las muestras de cortesía en el trato revelan que es un personaje de clase alta, y así se le califica como "político pastor". Después del encuentro "se sentaron al pie de un robusto roble" y el pas-

77 “¿Qué bien podrá esperar quien ha dexado / hermosa Polinarda tu presencia / en quien el más subido está criado? / Pues verme es muerte con tan larga ausencia / aunque no en tu desgracia, que esso fuera / ver a perpetua pena la sentencia”. 
tor se dispuso a contar su historia, todo un episodio interpolado que, como se ha visto, coincide en su presentación con uno de los motivos comentados por González Rovira, el lamento de amor $^{78}$. La historia de este personaje es un relato de amor no correspondido y rivalidad amorosa que poco tiene que ver con lo pastoril y, de alguna manera, se acerca más a los temas que trata lo que se ha denominado novela cortesana (o novela corta) que a la tradición caballeresca ${ }^{79}$.

En definitiva, Marcos Martínez introduce elementos pastoriles, pero no se ajusta a la figura del pastor idealizado, pues en algunos casos estos pastores dan muestras de amor hereos y de una clara lujuria, y, en otros, el pastor se revela como un personaje de clase superior, manteniéndose así una valoración propia de una rígida jerarquía social. Pero, en cualquier caso, lo que resulta evidente es que para la época en que escribe Marcos Martínez los elementos pastoriles (como el de la falsa soledad) se percibían como tópicos, a juzgar la exactitud con que el alcalaíno los refleja en su obra.

\section{Conclusiones}

Como hemos comprobado, la mayor parte de los libros de caballerías que se publican durante el reinado de Felipe II incorporaron, de una manera u otra, elementos pastoriles. Sin embargo, no se ha de percibir como una fusión de géneros motivada por el éxito de La Diana de Montemayor. Los elementos bucólicos ya eran frecuentes en la producción caballeresca anterior a la aparición de la obra del portugués, de forma que los autores de libros de caballerías se limitaban a seguir una tendencia existente en el género. Sin duda, la obra de Montemayor influyó, y el hecho de que Pedro de la Sierra imitara algunos de sus poemas es buena prueba de ello. Pero la impronta de la novela pastoril no es la única que determina los episodios p. 742.

${ }^{78}$ Javier GonzÁlez Rovira, "Poética y retórica del relato interpolado",

${ }^{79}$ Sin embargo, estos temas de alcoba no eran infrecuentes en las obras caballerescas, como sabrá todo lector de Feliciano de Silva. En efecto, incluso una obra caballeresca breve tan temprana como El libro del rey Canamory de Turián narra situaciones que recuerdan al Decamerón de Bocaccio más que a la tradición artúrica. De nuevo, el análisis de toda la producción caballeresca resulta necesario para comprender la aparición de géneros del setecientos, como la novella. 
bucólicos en los libros de caballerías, junto a ella se encuentran las églogas de Garcilaso y de todos sus seguidores; incluso no se ha de descartar una influencia del teatro pastoril de tradición enciniana. De todas formas, como se ha visto, Feliciano de Silva influyó más que Montemayor en los episodios bucólicos en los libros de caballerías.

Por otra parte, la temática pastoril en los libros de caballerías parece responder a una serie de tópicos. En primer lugar encontramos, con mucha frecuencia, que los libros de caballerías de esta época no parecen aceptar la idea de un pastor idealizado; así, se nos presenta un pastor que finalmente se descubre que no es tal, sino un personaje de clase alta. Esto sucede en el Olivante de Laura (1564) y en la Segunda parte de Espejo de príncipes y caballeros (1580). Este personaje que vive como pastor sin serlo puede ser un hombre (Silvano en el Olivante) o una mujer (Caicerlinga en la Segunda parte de Espejo). En ambos casos estos personajes se han criado desde niños como pastores e ignoran su verdadero linaje. Se puede considerar que el origen caballeresco es el personaje de Silvia en el Amadís de Grecia (1530) de Silva. Relacionado con este tema encontramos la transformación del caballero en pastor por motivos amorosos, porque el caballero se enamora de un pastora (como el caso de la Segunda parte de Espejo) o porque, enamorado de una alta dama, el disfraz pastoril le permite mayor cercanía (Olivante de Laura). El primer caso se relaciona con el modelo de Florisel, que vive como pastor al enamorarse de Silvia, en el Amadís de Grecia; para el segundo caso, el modelo de nuevo es Feliciano, en concreto, la historia de Rogel de Grecia quien se disfraza de pastor (bajo el nombre de Arquileo) para poder estar cerca de su amada, la emperatriz Arquisidea, en la Cuarta parte de Florisel de Niquea (1551).

En otras ocasiones aparecen verdaderos pastores idealizados, que cantan sus penas de amor como si de cortesanos o caballeros se tratara. Esto sucede en la Segunda parte de Espejo de príncipes y en Febo el Troyano, que no son las primeras en incorporarlos, pues no hemos de olvidar a Darinel, el pastor enamorado de Silvia en el Amadís de Grecia, de Feliciano.

Junto a los aspectos analizados, encontramos otros lugares comunes en estos episodios pastoriles de obras caballerescas: los debates (tanto sobre el sentimiento amoroso como sobre el valor de la mujer, cuestiones claramente vinculadas), y, relacionada con ellos, la aparición del pastor desamorado, que discrepa de las opiniones de los pastores enamorados. Otros tópicos 
son los propios de toda la literatura bucólica: el reflejo idealizado de la naturaleza, el concepto elevado del sentimiento amoroso, la falsa soledad (que no sólo se encuentra en los libros de pastores sino también en la lírica pastoril) o el lamento de amor.

El siguiente esquema recoge los motivos pastoriles más frecuentes en los libros de caballerías de la época de Felipe II:

1. Pastor(a) que en realidad es noble.

2. La transformación del caballero en pastor

2.1. por amada pastora,

2.2. por amada noble.

3. Debates

3.1. sobre el amor,

3.2. debate sobre la mujer.

4. Aparición de un pastor desamorado.

Por tanto, junto a una serie de lugares comunes propios de la literatura pastoril en general, los libros de caballerías adoptaron, en el siglo XVI, una serie de tópicos bucólicos propios (propios no porque no se pudieran dar en otros géneros, sino porque es a ellos a los que recurren los autores de obras caballerescas). Quizá porque con estos tópicos pretenden solucionar el contraste entre el mundo caballeresco (con su rígida estructura social) y el pastoril (en el que las fronteras sociales se difuminan). Cada autor de libro de caballerías resolvió a su manera esta confrontación, pero a partir de la segunda mitad del siglo Xvi cabe pensar que se prefería esta confrontación a eliminar el bucolismo de manera absoluta. Por otra parte, parece claro que Silva fue el principal modelo que posteriormente tomó el resto de libros de caballerías que insertaron elementos pastoriles, influencia que, a partir de 1559, se fundió con la impronta de Montemayor ${ }^{80}$. Por tanto, más que fusión genérica, la aparición del bucolismo en los libros de caballerías se debe a la acentuación de unas posibilidades genéricas abiertas por Silva y que la publicación de La Diana tan sólo reforzó.

\section{José Julio Martín Romero \\ Universidad de Jaén}

\footnotetext{
${ }^{80} \mathrm{Y}$ siempre, junto a todas estas influencias, se encuentra el recuerdo de Garcilaso.
} 
